\title{
Should Greenhouse Gas Permits be Allocated on a Per Capita Basis?
}

\section{Citation}

Eric Posner \& Cass R. Sunstein, Should Greenhouse Gas Permits be Allocated on a Per Capita Basis?, 97 Calif. L. Rev. 51 (2009).

\section{Published Version}

http://chicagounbound.uchicago.edu/journal_articles/1760/

\section{Permanent link}

http://nrs.harvard.edu/urn-3:HUL.InstRepos:13015045

\section{Terms of Use}

This article was downloaded from Harvard University's DASH repository, and is made available under the terms and conditions applicable to Other Posted Material, as set forth at http:// nrs.harvard.edu/urn-3:HUL.InstRepos:dash.current.terms-of-use\#LAA

\section{Share Your Story}

The Harvard community has made this article openly available.

Please share how this access benefits you. Submit a story.

\section{Accessibility}




\section{University of Chicago Law School Chicago Unbound}

Journal Articles

Faculty Scholarship

2009

\section{Should Greenhouse Gas Permits be Allocated on a Per Capita Basis?}

Eric Posner

Cass R. Sunstein

Follow this and additional works at: http://chicagounbound.uchicago.edu/journal_articles Part of the Law Commons

\section{Recommended Citation}

Eric Posner \& Cass R. Sunstein, "Should Greenhouse Gas Permits be Allocated on a Per Capita Basis?," 97 California Law Review 51 (2009).

This Article is brought to you for free and open access by the Faculty Scholarship at Chicago Unbound. It has been accepted for inclusion in Journal Articles by an authorized administrator of Chicago Unbound. For more information, please contact unbound@law.uchicago.edu. 


\title{
Should Greenhouse Gas Permits Be Allocated on a Per Capita Basis?
}

\author{
Eric A. Posner $\uparrow$ \\ Cass R. Sunstein $\dagger \dagger$
}

\begin{abstract}
Many people believe that the problem of climate change would be best handled by an international agreement that includes a system of "cap-andtrade." Such a system would impose a global cap on greenhouse gas emissions and allocate tradable emissions permits. This proposal raises a crucial but insufficiently explored question: How should such permits be allocated? It is tempting to suggest that in principle, a cap-and-trade system should allocate permits on a per capita basis, with the idea that each person should begin with the same entitlement, regardless of place of birth. This idea, pressed by many analysts and by the developing world, can be defended on grounds of either welfare or fairness. But on both grounds, per capita allocations run into serious objections. If fairness is understood in terms of equally or proportionally sharing the burdens of a climate treaty, per capita allocations are not fair because they do not take into account all the effects of such a treaty. Any agreement to reduce greenhouse gas emissions will give more benefits to some nations than to others, and will impose more costs on some nations than on others; in these circumstances, per capita emissions rights give the appearance but not the reality of fairness. For those who seek redistribution to those who need help, on grounds of either welfare or fairness, per capita allocations of emissions rights are at best a mixed blessing. Some rich nations are highly populated, and some poor nations have small populations; there is essentially no relationship between size of population and per capita wealth.
\end{abstract}

Copyright $(\mathcal{C} 2009$ California Law Review, Inc. California Law Review, Inc. (CLR) is a California nonprofit corporation. CLR and the authors are solely responsible for the content of their publications.

$\dagger \quad$ Kirkland \& Ellis Professor, University of Chicago Law School.

i† Felix Frankfurter Professor of Law, Harvard Law School; Harry Kalven Visiting Professor of Law, University of Chicago, January 2009. Thanks to Joe Aldy, Robert Hahn, and David Weisbach for comments and Sung Eun Jung and Adam Wells for research assistance. 
Per capita allocations would also create serious incentive problems, and they would face decisive objections from the standpoint of feasibility: Per capita rights would transfer hundreds of billions of dollars annually from the United States to China and India, and the United States is most unlikely to sign a treaty with that consequence. Per capita allocations must be compared with other approaches, including those based on existing emissions rates and those with self-conscious redistributive aims. Any system of allocation should balance welfarist and fairness goals with feasibility constraints; per capita allocations do a poor job of achieving that balance, and an insistence on that approach might make it impossible for nations to agree on a climate treaty. These conclusions have general implications for thinking about normative goals and practical limitations in the context of international law.

\section{INTRODUCTION}

Many people believe that the problem of climate change should be handled by some kind of international cap-and-trade system. ${ }^{1}$ Under this approach, participating nations, and perhaps the entire world, would create a "cap" on greenhouse gas emissions. Nations would be allocated specified emissions rights, which could be traded in return for cash. A system of this kind might well be the most effective and efficient method of reducing emissions. ${ }^{2}$

By itself, however, the proposal for a cap-and-trade system does not answer a crucial question: How should such a system allocate emissions rights? It is tempting to suggest that the status quo, across nations, provides the appropriate baseline. On one view, emissions might be frozen at existing levels, so that every nation has the right to its current level of emissions. On a more aggressive view, generally captured in the Kyoto Protocol, ${ }^{3}$ all or most signatory nations should reduce their emissions levels by a specified percentage, again taking the status quo as the foundation for reductions. ${ }^{4}$ The status quo approach might have intuitive appeal, but it is also somewhat arbitrary and raises serious questions from the standpoint of equity. ${ }^{5}$ Why should climate change policy take existing national emissions, reflecting existing national energy uses, as a given for policy purposes? Should a nation with three hundred million people be given the same emissions rights as a nation with one billion people, or forty million people, simply because the emissions of the three nations, at the current time, are roughly equal?

1. See, e.g., Richard B. Stewart \& Jonathan B. Wiener, Reconstructing Climate Policy (2003).

2. See id.

3. See Kyoto Protocol to the United Nations Framework Convention on Climate Change, Dec. 10, 1997, 37 I.L.M. 22 (1998) [hereinafter Kyoto Protocol].

4. This is an oversimplification. See Cass R. Sunstein, Worst-Case Scenarios 87-90 (2007), for qualifications.

5. William D. Nordhaus \& Joseph Boyer, Warming the World 149-168 (2000). 
Raising these questions, many observers have strenuously urged that in an international agreement, emissions rights should be allocated by reference to population, not to existing emissions. ${ }^{6}$ The intuition here is that every person on the planet should begin with the same emissions right; it should not matter whether people find themselves in a nation whose existing emissions rates are low or high. Those concerned about the welfare of developing nations are especially interested in per capita allocations of emissions rights. ${ }^{7}$ Why should a poor nation with a large population be required to stick close to its current emissions level, when wealthy nations with identical populations are permitted to emit far more? Why should existing distributions of wealth, insofar as they are reflected in current emissions, form the foundation for climate change policy? More bluntly: Why should the United States be given emissions rights that dwarf those of, say, India, which has a much larger population?

This argument might well be connected with a general "right to development." ${ }^{8}$ If the status quo is the baseline for allocating emissions rights,

6. See, e.g., National Development and Reform Commission, People's Republic of China, China's National Climate Change Programme 58 (2007), available at www.ccchina.gov.cn/WebSite/CCChina/UpFile/File188.pdf [hereinafter CHINA's NaTIONAL Climate Change Programme]; Daniel Bodansky, Pew Center on Global Climate Change, International Climate Efforts Beyond 2012: A Survey of Approaches (2004), available at www.pewclimate.org/docUploads/2012\%20new.pdf (describing several per capita approaches); AnIL Agarwal, Making the Kyoto Protocol Work: Ecological and ECONOMic EFFectiveness, and Equity IN THE Climate Regime, available at http://www.cseindia.org/html/eyou/climate/pdf/cse_stat.pdf; ANIL AGARWAL ET AL., GLOBaL Warming in an Unequal World (1991); Tom Athanasiou \& Paul Baer, Dead Heat (2002); Donald A. Brown, American Heat 214 (2002); Peter Singer, One World 35 (2002); Ann P. Kinzig \& Daniel M. Kammen, National Trajectories of Carbon Emissions: Analysis of Proposals to Foster the Transition to Low-Carbon Economies, 8 Global ENvTL. Change 183 (1998); Juliane Kokott, Equity in International Law, in Falr Weather? 173, 188 (Ferenc L. Tóth ed., 1999); Hermann E. Ott \& Wolfgang Sachs, The Ethics of International Emissions Trading, in Ethics, Equity and InTERnational Negotiations on Climate Change 159, 159-68 (Luiz Pinguelli-Rosa \& Mohan Munasinghe eds., 2002) ("The equal right of all world citizens to the atmospheric commons is therefore the cornerstone of any viable climate regime."); Ambuj D. Sagar, Wealth, Responsibility, and Equity: Exploring an Allocation Framework for Global GHG Emissions, 45 Climatic Change 511 (2000); Sven Bode, Equal Emissions per Capita over Time-A Proposal to Combine Responsibility and Equity of Rights (Hamburg Inst. of Int'1 Econ., Discussion Paper No. 253, 2003), available at http://papers.ssrn.com/sol3/papers.cfm?abstract_id=477281; see also J. TimMONS ROBERTS \& BRADLEY C. PARKs, A Climate OF INJUSTICE 144-46 (2007) (describing international support for the per capita approach); STeve VANDERHEIden, ATMOSPHERIC Justice (2008); Juan-Carlos Altamirano-Cabrera \& Michael Finus, Permit Trading and Stability of International Climate Agreements, 9 J. Applied Econ. 19 (2006); Malik Amin Aslam, Equal Per Capita Entitlements: A Key to Global Participation on Climate Change?, in Building on the Kyoto Protocol: Options for Protecting the Climate 175 (Kevin A. Baumert ed., 2002); Jeffrey Frankel, Formulas for Quantitative Emissions Targets, in ARCHITECTURES FOR AGREEMENT 31, 40 (Joseph E. Aldy \& Robert N. Stavins eds., 2007) (noting developing world demand for per capita system).

7. See, e.g., China's National Climate Change Programme, supra note 6; AltamiranoCabrera \& Finus, supra note 6; Frankel, supra note 6; Kinzig \& Kammen, supra note 6.

8. See Declaration on the Right to Development, G.A. Res. 128, U.N. GAOR, 41st Sess., Supp. No. 53, U.N. Doc. A/41/53 (Dec. 4, 1986). 
poor nations are likely to have great difficulty in achieving the levels of development already attained by wealthy nations. Perhaps a climate change agreement based on existing national emissions rates would violate the "right to development" even if it would be both effective and efficient.

The significance of this controversy can hardly be exaggerated. The United States, long an obstacle to a climate treaty, finally committed itself at the 2007 climate conference at Bali to negotiate a treaty with binding greenhouse gas mitigation obligations. ${ }^{9}$ Any eventual treaty will almost certainly include a cap-and-trade system, as there is under the Kyoto Protocol. ${ }^{10}$ A cap-and-trade system has already been put in place in the European Union, ${ }^{11}$ and another is contained in bills currently before Congress. ${ }^{12}$ Most notably, the per capita approach has been described as "the most politically prominent contender for any specific, global formula for longterm allocations, with increasing numbers of adherents in both developed and developing countries," 13 including India, China, and as many as 130 other countries, and the European Union. ${ }^{14}$ However, the United States has obliquely indicated discomfort with the per capita system, arguing that developing countries that are, or will soon be, industrial powers-including China, India, and Brazil-will have to accept significant mitigation obligations in a climate treaty. ${ }^{15}$ It is unlikely, we will argue, that a per capita system will satisfy the demands of the United States, one of the world's leading greenhouse gas emitters on a per capita basis. Meanwhile, the per capita approach remains an influential political and ethical paradigm for the distribution of permits because it has not been subject to sustained challenge.

Our goal in this Article is to identify the problems with the per capita system, in terms of both principle and feasibility, and to suggest that its current prominence and popularity are undeserved. We suggest that advocates of per capita allocations are correct on one point: In principle, there is little to be said for basing emissions rights on existing emissions levels. The most plausible

9. See Bali Action Plan, $\llbracket 1$ (2007), available at http://unfccc.int/files/meetings/cop_13/ application/pdf/cp_bali_action.pdf.

10. For good outlines, see Stewart \& WIENER, supra note 1; Nordhaus \& Boyer, supra note 5, at 145-68. For a brisk and illuminating treatment of policy questions involving the climate change problem, with occasional reference to the Kyoto Protocol, see WILliam NordHaus, The Challenge of Global Warming: Economic Models and Environmental Policy (2007), available at $\mathrm{http}: / /$ nordhaus.econ.yale.edu/dice_mss_072407_all.pdf.

11. See United Nations Framework Convention on Climate Change, Clean Development Mechanism (CDM), About Clean Development Mechanism (CDM), Clean Development Mechanism, http://cdm.unfccc.int/about/index.html (last visited Aug. 10, 2008).

12. See John M. Broder, Senate Panel Passes Bill to Limit Greenhouse Gases, N.Y. TIMES, Dec. 6, 2007, at A39.

13. See Michael Grubb et al., The Kyoto Protocol 270 (1999).

14. ROBERTS \& PARKS, supra note 6, at 144.

15. See Press Release, The White House, Statement by the Press Secretary on the Decision of the Conference of the Parties in Bali on Climate Change (Dec. 15, 2007), available at http://www.whitehouse.gov/news/releases/2007/12/20071215-1.html. 
defense of this approach is pragmatic. Nations are unlikely to sign an international agreement if they will be significant net losers, ${ }^{16}$ and wealthy nations might lose a great deal from any approach that does not use existing emissions as the baseline for reductions. But this pragmatic point shows only that powerful nations might well veto approaches that are better in principle; it does not show that those nations would be correct to do so. As a normative matter, an approach based on per capita emissions rights seems preferable to one based on existing emissions; there are strong intuitive claims, rooted in welfarist and other arguments, on behalf of such an approach.

As we shall see, however, a per capita approach runs into powerful objections. We demonstrate this point by comparing the per capita approach to several others, above all, those based on existing emissions and those with explicitly redistributive aims. Most fundamentally, per capita allocations will help some rich nations and hurt some poor ones. The reason is that some rich nations are highly populated, and some poor nations are not. In fact there is no correlation between population size and wealth per capita. ${ }^{17}$ If global redistribution or international justice is the goal, the per capita approach is a highly imperfect means. From the standpoint of those who favor assistance to poor people in poor nations, per capita emissions allocations are far less attractive than they seem. In some cases, the per capita approach actually creates perverse incentives. From the standpoint of global redistribution of wealth-justified on grounds of either welfare or fairness-other approaches, more directly focused on these central goals, would be much better. A key point here, insufficiently appreciated in the current debate, is that any emissions reduction agreement will impose a disparate array of costs and benefits, varying greatly across nations; in these circumstances, a per capita approach turns out to have far less appeal on reflection than on first glance.

Many people support the per capita approach not on redistributive grounds, but on the basis of a simple and plausible appeal to fairness. ${ }^{18}$ The atmosphere's carbon-absorbing features are naturally thought of as a common resource. Perhaps a common resource should be divided among all the people in the world on the ground that all people enjoy a right to equal opportunity or to equal human dignity. ${ }^{19}$ Indeed, the same type of argument has been made about mineral resources discovered under the high seas: as no particular state "owns" these resources, they should be divided on a per capita basis. ${ }^{20}$ And

16. See Jack L. Goldsmith \& Eric A. Posner, The Limits of International Law (2005).

17. See infra note 52 and accompanying text.

18. See, e.g., Michael Grubb, James Sebenius, Antonio Magalhaes \& Susan Subak, Sharing the Burden, in Confronting Climate Change: Risks, Implications \& Responses 318-19 (Irving M. Mintzer ed., 1992).

19. Universal Declaration of Human Rights, G.A. Res. 217A, art. 1, U.N. GAOR, 3d Sess., 1 st plen. mtg., U.N. Doc A/810 (Dec. 12, 1948).

20. The Law of the Sea Convention provides that such resources be divided "equitably." 
given the constraints of national sovereignty, the resources should be given to national governments on the basis of their states' share of the global population rather than divided up among individuals directly.

We will show that the analogy to common property is at best incomplete and obscures the relevant moral concerns. If we compare a climate treaty and a treaty that provides for the exploitation of an underwater mineral deposit, we immediately see that there is a crucial difference between the two settings. A climate treaty, by reducing global warming, will have differential benefits and costs for people around the world. While some people will benefit a great deal, others will benefit much less or perhaps not at all. By contrast, exploitation of mineral deposits has minimal differential effects. Per capita distribution of greenhouse gas emission permits would distribute the revenues from the abatement program on an equal basis, but would not equalize the overall effects of that program.

In principle, the appropriate way to distribute permits is on the basis of the aggregate effects of the climate treaty in light of standard normative theories-emphasizing, for example, distributive justice, welfare, or fairness. From the standpoint of those theories, and in particular on welfarist grounds, the per capita approach does have major advantages over an approach based on existing emissions because it would provide significantly greater benefits to poor people. But the per capita approach would also have some unfortunate incentive effects, which complicate the inquiry. Even if those effects are put to one side, a per capita approach is far inferior to an approach that focuses more concretely on what the right normative theory requires.

We shall also explore a series of pragmatic problems with the per capita approach, including its incentive effects with respect to future international agreements and population growth. A pervasive question involves feasibility. The problem of climate change cannot be successfully addressed without an international agreement that includes all or almost all of the major contributors. Per capita allocations would have the effect of redistributing hundreds of billions of dollars from wealthy nations, above all the United States, to developing nations, above all China and India. For this reason, insistence on per capita allocations would effectively doom any climate change agreement. We offer some brief remarks about the relationship between this pragmatic constraint and some of the underlying questions of principle.

Our conclusions are that on welfarist grounds, the per capita approach is at most a crude second-best, and that it faces decisive objections from the standpoint of feasibility. Insistence on that approach would effectively doom an international effort to reduce the risks associated with climate change. And

However, that term has multiple meanings and is left undefined. See United Nations Convention on the Law of the Sea, Dec. 10, 1982, 1833 U.N.T.S. 397 [hereinafter Law of the Sea Convention]. 
while our focus throughout is on the problem of climate change, the analysis will have general implications for issues of international law, where treaty development frequently raises questions about the relationships among welfare, faimess, and feasibility. ${ }^{21}$ Despite those general implications, we should stress that our goals are, in one sense, quite modest. We do not attempt to sketch a climate change agreement here, and we do not mean to reach a general conclusion on how emissions rights should, in fact, be allocated. In establishing the problems with per capita allocations, we mean to take one step along the way toward answering the most difficult questions about the relationships among climate change, welfare, and justice.

Part I of this Article describes current and projected emissions rates of major global contributors. Part II explains the subtle distributive effects of the per capita approach, compared to other approaches. Part III, the heart of the Article, shows that the per capita approach is unattractive on welfarist and fairness grounds. Part IV argues that the per capita approach, even if appealing in principle, is unlikely to be feasible.

\section{AggRegate EMISSIONS Versus Per CAPITA EMISSIONS}

In this Part, we provide relevant facts in order to provide a background for analysis of possible allocation schemes. We are aware that particular estimates are much disputed and that they are subject to change over time. Our principal goal is not to insist on specific numbers, but to establish that there are dramatic differences between national emissions in the aggregate and national emissions on a per capita basis.

\section{A. Aggregate Emissions}

An international agreement might allocate greenhouse gas (GHG) emissions rights in many different ways. If existing national emissions rates are used as the guide, a recent ranking across nations would look like this: ${ }^{22}$

21. An especially helpful discussion is Scott Barrett, Environment and Statecraft 335-358 (2003).

22. Tables generated by World Resources Institute, Climate Analysis Indicators Tool, http://cait.wri.org/cait.php?page=yearly (last visited Aug. 14, 2008) [hereinafter Climate Analysis Indicators Tool]. Excludes land use change. 
Table 1: GHG Emissions-Total CO2 Emissions in 2004

\begin{tabular}{|c|l|r|}
\hline Rank & \multicolumn{1}{|c|}{ Country } & $\begin{array}{c}\text { Millions of } \\
\text { Metric Tons } \\
\text { CO }_{2}\end{array}$ \\
\hline 1 & United States & $5,888.7$ \\
\hline 2 & China & $5,204.8$ \\
\hline 3 & European Union (25) & $4,017.1$ \\
\hline 4 & Russian Federation & $1,575.3$ \\
\hline 5 & Japan & $1,304.2$ \\
\hline 6 & India & $1,199.0$ \\
\hline 7 & Germany & 856.6 \\
\hline 8 & United Kingdom & 551.3 \\
\hline 9 & Canada & 549.1 \\
\hline 10 & Korea (South) & 507.0 \\
\hline 11 & Italy & 482.2 \\
\hline 12 & South Africa & 427.9 \\
\hline 13 & Mexico & 415.3 \\
\hline 14 & Iran & 407.6 \\
\hline 15 & France & 396.7 \\
\hline 16 & Indonesia & 368.0 \\
\hline 17 & Spain & 355.1 \\
\hline 18 & Australia & 350.9 \\
\hline 19 & Brazil & 346.2 \\
\hline 20 & Saudi Arabia & 342.9 \\
\hline 21 & Ukraine & 329.6 \\
\hline 22 & Poland & 304.0 \\
\hline 23 & Taiwan & 276.6 \\
\hline 24 & Thailand & 238.5 \\
\hline 25 & Turkey & 229.2 \\
\hline 26 & Netherlands & 187.1 \\
\hline 27 & Kazakhstan & 178.4 \\
\hline 28 & Egypt & 152.2 \\
\hline 29 & Malaysia & 149.2 \\
\hline 30 & Argentina & 145.6 \\
\hline 31 & Venezuela & 140.2 \\
\hline 32 & Uzbekistan & 131.9 \\
\hline 33 & Czech Republic & 125.2 \\
\hline 34 & Pakistan & 125.2 \\
\hline 35 & Belgium & 194.0 \\
\hline 36 & United Arab Emirates & \\
\hline & & \\
\hline
\end{tabular}




\begin{tabular}{|l|l|r|}
\hline 37 & Greece & 98.8 \\
\hline 38 & Romania & 96.1 \\
\hline 39 & Vietnam & 91.8 \\
\hline 40 & Algeria & 91.6 \\
\hline 41 & Nigeria & 85.1 \\
\hline 42 & Iraq & 84.4 \\
\hline 43 & Philippines & 80.3 \\
\hline 44 & Austria & 76.8 \\
\hline 45 & Korea (North) & 73.1 \\
\hline 46 & Finland & 72.1 \\
\hline 47 & Kuwait & 70.5 \\
\hline 48 & Belarus & 65.9 \\
\hline 49 & Portugal & 65.1 \\
\hline 50 & Israel & 63.8 \\
\hline 51 & Chile & 63.4 \\
\hline 52 & Colombia & 61.7 \\
\hline 53 & Hungary & 58.9 \\
\hline 54 & Serbia \& Montenegro & 56.7 \\
\hline 55 & Sweden & 56.1 \\
\hline 56 & Denmark & 52.6 \\
\hline 57 & Syria & 51.7 \\
\hline 58 & Singapore & 50.1 \\
\hline 59 & Libya & 49.8 \\
\hline 60 & Bulgaria & 47.4 \\
\hline 61 & Switzerland & 44.6 \\
\hline 62 & Ireland & 43.6 \\
\hline 63 & Norway & 42.4 \\
\hline 64 & Slovakia & 39.8 \\
\hline 65 & Turkmenistan & 39.5 \\
\hline 66 & Qatar & 39.1 \\
\hline 67 & Morocco & 38.5 \\
\hline 68 & Bangladesh & 37.5 \\
\hline 69 & New Zealand & 33.1 \\
\hline 70 & Oman & 31.9 \\
\hline 71 & Azerbaijan & 30.9 \\
\hline 72 & Peru & 29.6 \\
\hline 73 & Ecuador & 28.2 \\
\hline 74 & Cuba & 25.1 \\
\hline 75 & Tunisia & \\
\hline & Total for top 75 GHG emitters & \\
\hline & & 30.8 \\
\hline
\end{tabular}

It is evident that the world's leading emitters account for a strikingly large 
percentage of the world's emissions. Indeed, the United States and China, by themselves, are responsible for about forty percent of the world's total. Most of the world's nations, including many poor countries, are trivial contributors.

Estimates suggest that the largest contributors are likely to continue to qualify as such. But major shifts will occur, above all with emissions growth in China and India, and emissions reductions in Russia and Germany.

Table 2: Carbon Dioxide Emissions Changes, 1990-2004 ${ }^{23}$

\begin{tabular}{|l|r|}
\hline \multicolumn{1}{|c|}{ Country } & $\begin{array}{r}\text { \% Change } \\
\text { 1990-2004 }\end{array}$ \\
\hline China & $108.3 \%$ \\
\hline United States & $19.8 \%$ \\
\hline India & $87.5 \%$ \\
\hline South Korea & $104.6 \%$ \\
\hline Iran & $110.7 \%$ \\
\hline Indonesia & $137.7 \%$ \\
\hline Saudi Arabia & $85.6 \%$ \\
\hline Brazil & $67.8 \%$ \\
\hline Spain & $59.0 \%$ \\
\hline Pakistan & $96.6 \%$ \\
\hline Poland & $-15.3 \%$ \\
\hline EU-25 & $1.6 \%$ \\
\hline Germany & $-12.2 \%$ \\
\hline Ukraine & $-47.1 \%$ \\
\hline Russia & $-24.8 \%$ \\
\hline
\end{tabular}

With these trends, we can offer a rough projection of changes to 2030. At that time, the developing world is expected to contribute no less than fifty-five percent of total emissions, and developed nations are expected to contribute forty-five percent. ${ }^{24}$ The United States is expected to be well below China. Here is one projection of changes in emissions rates over time:

23. Emissions of $\mathrm{CO} 2$ from energy-related sources only. See Int'l Energy Agency [IEA], CO2 EMISSIONS FROM FUEL COMBUSTION: 197 I-2004, II.4-II.7 (IEA Statistics 2006) [hereinafter CO2 EMISSIONS FROM FUel COMBUSTION: 1971-2004].

24. EnERgy Information Administration, OfFice of Integrated ANalysis and Forecasting, U.S. DeP't Energy, International Energy OUtlook 2007 93, tbl.Al, available at http://www.eia.doe.gov/oiaf/archive/ieo07/pdf/0484(2007).pdf. 
Table 3: Relative Contributions of Annual Carbon Dioxide Emissions by Country/Region (Approximate \% of Worldwide Emissions) ${ }^{25}$

\begin{tabular}{|l|r|r|r|r|r|r|r|r|}
\hline & $\mathbf{1 9 9 0}$ & $\mathbf{2 0 0 3}$ & $\mathbf{2 0 0 4}$ & $\mathbf{2 0 1 0}$ & $\mathbf{2 0 1 5}$ & $\mathbf{2 0 2 0}$ & $\mathbf{2 0 2 5}$ & $\mathbf{2 0 3 0}$ \\
\hline $\begin{array}{l}\text { United } \\
\text { States }\end{array}$ & $23.5 \%$ & $22.7 \%$ & $22.0 \%$ & $20.1 \%$ & $19.4 \%$ & $18.8 \%$ & $18.7 \%$ & $18.5 \%$ \\
\hline $\begin{array}{l}\text { OECD } \\
\text { Europe }\end{array}$ & $19.3 \%$ & $16.9 \%$ & $16.3 \%$ & $14.6 \%$ & $13.4 \%$ & $12.4 \%$ & $11.6 \%$ & $10.9 \%$ \\
\hline China & $10.5 \%$ & $15.3 \%$ & $17.5 \%$ & $21.1 \%$ & $22.4 \%$ & $23.9 \%$ & $25.0 \%$ & $26.2 \%$ \\
\hline India & $2.7 \%$ & $4.1 \%$ & $4.1 \%$ & $4.2 \%$ & $4.4 \%$ & $4.7 \%$ & $4.9 \%$ & $5.0 \%$ \\
\hline Japan & $4.8 \%$ & $4.9 \%$ & $4.7 \%$ & $4.1 \%$ & $3.8 \%$ & $3.5 \%$ & $3.3 \%$ & $3.0 \%$ \\
\hline Africa & $3.1 \%$ & $3.5 \%$ & $3.4 \%$ & $3.7 \%$ & $3.8 \%$ & $3.9 \%$ & $3.9 \%$ & $3.9 \%$ \\
\hline
\end{tabular}

For our purposes, the most noteworthy changes involve the world's two most populous nations, India and China, which will be responsible for nearly one-third of the world's emissions in the relatively near future. And while this projection is fairly recent, it is already outdated because of unanticipated explosive emissions growth in the developing world. For example, China apparently surpassed the United States in aggregate $\mathrm{CO}_{2}$ emissions in June 2007 or perhaps before. ${ }^{26}$

It should be clear, from these figures, why developing countries are most unlikely to be sympathetic to an approach that allocates emissions rights on the basis of existing emissions levels. Their own emissions are expanding rapidly, and such an approach would be especially costly to them because it would force them to purchase emissions rights from other nations in order to develop at current rates. For example, India is not likely to be especially enthusiastic about the idea that if it is to develop at the rate indicated by "business as usual," it must spend a great deal of money to obtain permits from the United States, Russia, China, or Japan. Notwithstanding this point, it might be tempting to infer, from the numbers projected over the next decades, that an international agreement should allow China and the United States roughly the same level of emissions rights, and that the treatment of India should parallel the treatment of Japan. An approach of this kind would build on that of the Kyoto Protocol, which, as noted, requires percentage reductions from the status quo.

\section{B. Per Capita Emissions}

The most obvious objection to the status quo approach is that the figures for per capita emissions are radically different. On a per capita basis, China and India emerge as far more modest contributors, ranking well below Barbados,

25. See $\mathrm{CO}_{2}$ Emissions from Fuel COMBustion: 197 I-2004, supra note 23.

26. See Audra Ang, China Tops US in Carbon Emissions, Boston Globe, June 21, 2007 available at http://www.boston.com/news/world/asia/articles/2007/06/21/china_tops_us_in_ carbon_emissions. 
Croatia, Hungary, and Uzbekistan. To see the dramatic differences between aggregate emissions and per capita emissions, consider the following:

Table 4: GHG Emissions-Tons CO2 per Person in $2004^{27}$

\begin{tabular}{|c|l|r|}
\hline Rank & \multicolumn{1}{|c|}{ Country } & $\begin{array}{r}\text { Tons CO } \\
\text { Per Person }\end{array}$ \\
\hline 1 & Qatar & 50.3 \\
\hline 2 & Kuwait & 28.6 \\
\hline 3 & Luxembourg & 25.8 \\
\hline 4 & Brunei & 24.4 \\
\hline 5 & United Arab Emirates & 24.1 \\
\hline 6 & Bahrain & 22.9 \\
\hline 7 & United States of America & 20.1 \\
\hline 8 & Equatorial Guinea & 18.0 \\
\hline 9 & Australia & 17.5 \\
\hline 10 & Canada & 17.2 \\
\hline 11 & Trinidad \& Tobago & 16.8 \\
\hline 12 & Saudi Arabia & 15.2 \\
\hline 13 & Finland & 13.8 \\
\hline 14 & Estonia & 13.3 \\
\hline 15 & Oman & 12.6 \\
\hline 16 & Czech Republic & 12.3 \\
\hline 17 & Taiwan & 12.2 \\
\hline 18 & Palau & 11.9 \\
\hline 19 & Kazakhstan & 11.9 \\
\hline 20 & Singapore & 11.8 \\
\hline 21 & Netherlands & 11.5 \\
\hline 22 & Belgium & 11.4 \\
\hline 23 & Nauru & 11.2 \\
\hline 24 & Russian Federation & 11.0 \\
\hline 25 & Ireland & 10.7 \\
\hline 26 & Korea (South) & 10.5 \\
\hline 27 & Germany & 10.4 \\
\hline 28 & Japan & 9.2 \\
\hline 29 & Cyprus & 9.7 \\
\hline 30 & Denmark & 9.4 \\
\hline 31 & Austria & 9.2 \\
\hline 32 & Israel & \\
\hline 33 & South Africa & \\
\hline & & \\
\hline
\end{tabular}

27. Tables generated by Climate Analysis Indicators Tool, supra note 22 . Excludes land use change. 


\begin{tabular}{|c|c|c|}
\hline 34 & Norway & 9.2 \\
\hline 35 & United Kingdom & 9.2 \\
\hline 36 & Greece & 8.9 \\
\hline 37 & European Union (25) & 8.8 \\
\hline 38 & Libya & 8.7 \\
\hline 39 & Spain & 8.3 \\
\hline 40 & Italy & 8.3 \\
\hline 41 & Turkmenistan & 8.3 \\
\hline 42 & Slovenia & 8.2 \\
\hline 43 & New Zealand & 8.1 \\
\hline 44 & Poland & 8.0 \\
\hline 45 & Iceland & 7.9 \\
\hline 46 & Slovakia & 7.4 \\
\hline 47 & Serbia \& Montenegro & 7.0 \\
\hline 48 & Ukraine & 6.9 \\
\hline 49 & Belarus & 6.7 \\
\hline 50 & France & 6.6 \\
\hline 51 & Seychelles & 6.5 \\
\hline 52 & Bahamas & 6.3 \\
\hline 53 & Malta & 6.3 \\
\hline 54 & Sweden & 6.2 \\
\hline 55 & Portugal & 6.2 \\
\hline 56 & Bulgaria & 6.1 \\
\hline 57 & Iran & 6.1 \\
\hline 58 & Switzerland & 6.0 \\
\hline 59 & Malaysia & 6.0 \\
\hline 60 & Hungary & 5.8 \\
\hline 61 & Venezuela & 5.4 \\
\hline 62 & Barbados & 5.3 \\
\hline 63 & Suriname & 5.2 \\
\hline 64 & Uzbekistan & 5.1 \\
\hline 65 & Antigua \& Barbuda & 5.1 \\
\hline 66 & Croatia & 5.0 \\
\hline 67 & Lebanon & 4.8 \\
\hline 68 & Romania & 4.4 \\
\hline 69 & Macedonia, FYR & 4.3 \\
\hline 70 & Jamaica & 4.1 \\
\hline 71 & Mexico & 4.1 \\
\hline 72 & Bosnia \& Herzegovina & 4.0 \\
\hline 73 & China & 4.0 \\
\hline 74 & Chile & 3.9 \\
\hline 75 & Lithuania & 3.8 \\
\hline
\end{tabular}


The most striking point here is that while China has become the world's leading national emitter of greenhouse gases, its per capita contributions remain modest, ranking it near the bottom of the list of the seventy-five highest contributors. China's per capita emissions are merely one-fifth those of the United States, making it natural to question whether the two nations should be treated similarly in a climate change agreement.

The case of India may be even more pertinent. India's rapidly growing emissions rank it among the world's leaders on an absolute basis, but its per capita emissions are less than a third of those of China, about a sixth of those of France, and about one-fifteenth of those of the United States, ranking it one hundred twenty-second in the world. ${ }^{28}$

It should be clear that per capita allocations would produce radically different distributional effects from allocations based on the national status quo. Under a per capita system, the world's largest nations - China and India-would be significant net gainers. Indeed, their emissions rights would undoubtedly be worth large sums of money. The principal losers would be the nations that currently have high per capita emissions. The biggest loser, by far, would probably be the United States; indeed, the losses to the United States would likely be in the hundreds of billions of dollars. ${ }^{29}$ (For a simple comparison, those losses would, after a period of a decade, be well in excess of the cost of the Iraq War. ${ }^{30}$ ) Because of their high per capita emissions rates, Canada and Australia would lose a great deal as well.

With this background, we should be able to glimpse the intuitive argument on behalf of per capita allocations. Nations are not people; they are collections of people. A citizen of China should not be given emissions rights that are a small fraction of those of a citizen of the United States. Nor should a citizen of India be given emissions rights that constitute a small fraction of those of a citizen of Japan. Each person should count for no more and no less than one. ${ }^{31}$ As we shall see in Part III, this intuition might be grounded in concerns of

28. Id.

29. Under the status quo approach, the United States would be allocated about 20 percent of the permits (see Table 7). Under a per capita approach, the United States would be allocated about 5 percent of the permits (the U.S. share of the global population). Assuming that the price of a permit is $\$ 30$ per metric ton of $\mathrm{CO}_{2}$ (the approximate price in the EU market for the first half of 2008 ) and enough permits are supplied to permit the output rate of 30 billion metric tons per year (roughly the current global rate), then moving from the status quo approach (6 billion tons) to the per capita approach (1.5 billion tons) would cost the United States about $\$ 135$ billion per year. These are back-of-the-envelope calculations intended to give a rough sense of the magnitude involved, and should be taken with many grains of salt. See Mark Milner, Pollution: Value of Global Carbon Trading Is Already Nearly Double Last Year's Figure at f30bn, The GuARDian, July 9,2008 , at 43.

30. See Scott Wallsten, The Economic Cost of the Iraq War, Economists' Voice, Jan. 2006, available at $\mathrm{http}: / / \mathrm{www}$.bepress.com/cgi/viewcontent.cgi?article $=1134 \&$ context $=\mathrm{ev}$.

31. See Altamirano-Cabrera \& Finus, supra note 6, at 32. 
either welfare or fairness. But before we investigate these issues, it is necessary to untangle some complexities. An initial task is to obtain a better understanding of the effects of a per capita approach.

II

\section{A COMPARISON OF THE EFFECTS OF DifFERENT METHODS OF ALLOCATION}

In this section, we briefly describe the distributive effects of the per capita approach, and compare it to other approaches. Our goal is to show that in important ways, the actual effects are not what might be anticipated.

\section{A. Status Quo Approach}

Suppose that a firm consumes energy and other inputs to create goods that it sells on the market. Let us suppose that for every unit of energy that the firm consumes, it generates greenhouse gases that have a social cost of $\$ 10$.

One approach to greenhouse gas regulation would involve taxation. ${ }^{32}$ In this example, the optimal tax would be $\$ 10$ per unit of energy-the amount necessary to ensure that the firm uses a unit of energy only when the private benefit exceeds the social cost Alternatively (and identically), the firm could be prohibited from consuming energy unless it bought a permit from the government at a price of $\$ 10$. Let us stipulate that if the permit is traded, the price would be $\$ 10$ as well.

Both the tax system and the permit system would raise revenue as well as deter the emission of greenhouse gases. ${ }^{33}$ In this example, each system would generate revenue of $\$ 10$ per unit of energy. That money could be spent in any way; for example, the revenue could go into the treasury of the government that levied the tax or sold the permit, and then used for ordinary budget expenditures or to reduce general taxes. Note that the revenue raised would partially but not fully offset the immediate loss to consumer welfare in the form of higher prices. Firms would pass the tax along to consumers, who would either pay the higher price (and have less money to buy other things) or buy fewer energy-intensive goods. However, we assume that in the aggregate people would be better off: the environmental benefits would exceed the welfare losses from reduced consumption. ${ }^{34}$ Otherwise, there would be no reason to negotiate a climate treaty.

Now imagine that the world consists of two nations: Rich State and Poor State. Rich State has a large economy and relatively few people, while Poor State has a small economy and relatively many people. For concreteness, we

32. This approach is defended in Nordhaus, supra note 10.

33. In the example, we will ignore the different effects of the systems on energy use. We also assume throughout that the two different countries will distribute the permits allocated to them in the optimal fashion, such as through an auction.

34. We bracket the question whether and how animals should be treated. See Wayne Hsiung \& Cass R. Sunstein, Climate Change and Animals, 155 U. PA. L. Rev. 1695 (2007). 
might assume that Rich State is analogous to the United States and that Poor State is analogous to India. Suppose that Rich State consumes 100 units of energy at the time that the climate treaty goes into force, while Poor State consumes twenty units of energy. (For simplicity, we assume that Rich State and Poor State do not trade; citizens of each country consume the output of firms in that country.) Rich State has five citizens, while Poor State has twenty citizens. Thus, Rich State consumes twenty units of energy per citizen; Poor State consumes one unit of energy per citizen. Table 5 displays this information:

Table 5: An Example

\begin{tabular}{|l|r|r|rr|}
\hline & \multicolumn{1}{|c|}{$\begin{array}{c}\text { Aggregate energy } \\
\text { consumption }\end{array}$} & Population & \multicolumn{2}{|c|}{$\begin{array}{c}\text { Energy consumption per } \\
\text { capita }\end{array}$} \\
\hline Rich State & 100 & 5 & 20 \\
\hline Poor State & 20 & 20 & 1 \\
\hline
\end{tabular}

As we explained earlier, the tax system would require the government of each country to levy a $\$ 10$-per-unit tax on each firm - that is, a tax equal to the social cost of consumption of a unit of energy. Rich State would tax 100 units of energy and receive revenues of $\$ 1000$, while Poor State would tax twenty units of energy and receive revenues of $\$ 200$. Under the permit system, the treaty would authorize Rich State to sell one hundred permits and Poor State to sell twenty permits. As Table 6 shows, the distributive effects of each system would be the same: Rich State would raise $\$ 1000$ in revenue and Poor State would raise $\$ 200$ in revenue.

Table 6: Taxes versus Permits

\begin{tabular}{|c|r|r|r|r|c|}
\hline & $\begin{array}{c}\text { Aggregate } \\
\text { energy } \\
\text { consumption }\end{array}$ & $\begin{array}{c}\text { Tax per } \\
\text { unit of } \\
\text { energy }\end{array}$ & $\begin{array}{c}\text { Tax revenues } \\
\text { (first column x } \\
\text { second } \\
\text { column) }\end{array}$ & $\begin{array}{c}\text { Equivalent } \\
\text { permits }\end{array}$ & $\begin{array}{c}\text { Permit } \\
\text { revenue } \\
\text { at \$10 per } \\
\text { permit }\end{array}$ \\
\hline $\begin{array}{l}\text { Rich } \\
\text { State }\end{array}$ & 100 & $\$ 10$ & $\$ 1000$ & 100 & $\$ 1000$ \\
\hline $\begin{array}{l}\text { Poor } \\
\text { State }\end{array}$ & 20 & $\$ 10$ & $\$ 200$ & 20 & $\$ 200$ \\
\hline
\end{tabular}

We will call this the status quo approach because it takes as its baseline the relative use of energy in the status quo. ${ }^{35}$ If one thinks of the treaty as "creating" permits, then the treaty would distribute more permits to Rich State

35. In the literature, this approach is often called the "business-as-usual," "historical baseline," or "grandfathering" approach. See, e.g., RoBERTs \& PARKS, supra note 6, at 139. 
than to Poor State because Rich State consumes more energy than Poor State. The treaty would create a total of one hundred twenty permits, and give one hundred permits to Rich State and twenty permits to Poor State. Note that the effect of this treaty is identical to the tax approach described above.

As noted, the status quo approach to distribution is based on the amount of energy consumption at the time the treaty enters into force; it is analogous to the approach taken in the Kyoto Protocol. ${ }^{36}$ Because Rich State consumes five times as much energy as Poor State, Rich State receives five times as many permits as Poor State. And because wealthy countries consume more energy than poor countries, the status quo approach seems to favor wealthy countries. Of course, any judgment about whether particular nations are "favored" depends on a baseline. Rich State will surely point out that its own firms pay the revenue that it obtains from its extra permits, so that the effects wash out. It is puzzling that a uniform emissions tax is not intuitively taken to be unfair while the status quo approach to emissions rights is often found objectionable - even though the two are identical in their effects. But at least it can be said that the status quo approach will generally give more permits to wealthy nations than to poor ones, holding population constant, simply because wealthy nations tend to emit more greenhouse gases.

\section{B. Alternative Approaches}

Now let us consider some alternative approaches, including the per capita approach. For example, under the per nation approach, the treaty would distribute equal numbers of permits to every nation. Rich State and Poor State would each receive sixty permits. This approach also does not seem intuitively fair. All nations would receive the same number of permits, but they must spread the revenues from the permits among different numbers of citizens. In effect, Poor State's twenty citizens would receive three permits each; Rich State's five citizens would receive twelve permits each, though it is unlikely that the government would directly hand out permits to citizens.

The per capita approach seems much better on this score. Each nation would receive permits in proportion to its population. In our example, the climate treaty provides a total of one hundred twenty permits, so Poor State would receive ninety-six permits and Rich State would receive twenty-four permits. Each citizen in both countries would receive, in effect, 4.8 permits.

A final approach that we will consider will be called the redistributive approach. Under this approach, all the permits would be given to whichever country is poorer, at least up until the point at which wealth is equalized among countries. If we assume that Poor State is sufficiently poorer than Rich State, the redistributive approach would require that all one hundred twenty permits be given to Poor State. Poor State would then sell twenty permits to its own

36. See BARRETT, supra note 21 , at $358-98$. 
firms and one hundred to Rich State's firms, thus acquiring all the revenue from the permit system. Table 7 displays the permit allocations for the four approaches we have discussed:

\section{Table 7: Four Permit Allocation Schemes}

\begin{tabular}{|l|r|r|r|r|r|r|r|r|}
\hline & \multicolumn{2}{|c|}{ Status quo } & \multicolumn{2}{c|}{ Per nation } & \multicolumn{2}{c|}{ Per capita } & \multicolumn{2}{c|}{ Redistributive } \\
\hline & Permits & $\begin{array}{c}\text { Per } \\
\text { capita }\end{array}$ & Permits & $\begin{array}{c}\text { Per } \\
\text { capita }\end{array}$ & Permits & $\begin{array}{c}\text { Per } \\
\text { capita }\end{array}$ & Permits & $\begin{array}{c}\text { Per } \\
\text { capita }\end{array}$ \\
\hline $\begin{array}{l}\text { Rich } \\
\text { State }\end{array}$ & 100 & 20 & 60 & 12 & 24 & 4.8 & 0 & 0 \\
\hline $\begin{array}{l}\text { Poor } \\
\text { State }\end{array}$ & 20 & 1 & 60 & 3 & 96 & 4.8 & 120 & 6 \\
\hline
\end{tabular}

Other approaches are possible, including mixed approaches that fall between the various approaches described above. For example, one could allocate permits on the basis of a formula that weights both population size and poverty. ${ }^{37}$ For simplicity, however, we will confine our discussion to the four approaches described above: status quo, per nation, per capita, and redistributive.

\section{A Note on Ex Post Efficiency}

From what we will call the "ex post efficiency" perspective (our reasons for using this term will become clear later), all of these approaches are identical, assuming that the trading system works as planned. ${ }^{38}$ Ex post efficiency requires that energy users bear the social (climate) cost of energy use. If that cost is $\$ 10$ per unit of energy, then either a $\$ 10$ tax should be used, or states should create the number of permits such that the market price is $\$ 10$. All of our approaches allow states to set the price of the permits at $\$ 10$ or whatever the optimal price is, so they are all equally efficient.

The only differences among the approaches are distributive. As we saw, under the status quo approach, Rich State's government would receive one hundred permits and Poor State's government would receive twenty permits. Rich State would sell those hundred permits to the Rich State firms, and Poor State would sell the twenty permits to the Poor State firms. Under the per nation approach, Poor State would sell twenty of the permits to Poor State firms and forty of its permits to the remaining Rich State firms that were unable to purchase the sixty permits distributed to the Rich State government. Under the per capita approach, a similar outcome would occur. If Poor State would

37. See BoDANSKY, supra note 6, for a long list of proposals that weigh these factors and more.

38. For discussion, see NORdHaus \& BoYer, supra note 5, at 149-165 (showing that costs of climate change agreement are greatly decreased with significant emissions trading). 
receive ninety-six permits, its government would sell seventy-six to Rich State firms. The same would be true for the redistributive approach, as the Poor State government would sell one hundred of the one hundred twenty permits it had received to Rich State firms.

\section{Distribution}

We have seen that under the status quo system, Rich State would receive one hundred permits and Poor States would receive twenty permits. Because we assume that the social cost of consumption of a unit of energy is $\$ 10$, the permit price would also be $\$ 10$. The governments of each state would sell the permits, and receive revenues equal to product of the number of permits it sells and the price per permit. Thus, Rich State would raise revenues of $\$ 1000$ while Poor State would raise revenues of only $\$ 200$. By contrast, the per nation system would give Rich State revenues of $\$ 600$ from the sale of sixty permits and Poor State revenues of $\$ 600$ from the sale of sixty permits. The per capita system, where Poor State is four times more populous than Rich State, would give Poor State revenues of $\$ 960$ from the sale of ninety-six permits and Rich State revenues of $\$ 240$ from the sale of twenty-four permits. And under the redistributive system, Poor State would receive $\$ 1200$ from the sale of one hundred twenty permits and Rich State would receive $\$ 0$.

These are points about distribution across nations. But it is also important to understand the distributive effect of the various policies from a per capita standpoint. Under the status quo system, Rich State would receive $\$ 200$ per capita, while Poor State would receive $\$ 10$ per capita. Under the per nation system, Rich State would receive $\$ 120$ per capita, while Poor State would receive $\$ 30$ per capita. Under the per capita system, Rich State would receive $\$ 48$ per capita, as would Poor State. Under the redistributive approach, Rich State would receive $\$ 0$ per capita, while Poor State would receive $\$ 60$ per capita. $^{39}$

To obtain a fuller understanding of the distributive effects of the alternative approaches, we need to take into account the benefit side of the climate treaty. The permit system would reduce greenhouse gas emissions, resulting in mitigation of climate change. These benefits could be the same for Rich State and for Poor State, or different. It is well known that the benefits of reducing climate change are not constant across nations. ${ }^{40}$ Some nations have

39. The figures are obtained by multiplying the per capita permit distribution from Table 7 and $\$ 10$.

40. See, e.g., Climate Change Risk Report: Country-by-Country Risk Analysis and Mapping: 2008/2009 (2008) [hereinafter Climate Change Risk Report]; William R. Cline, Global Warming and Agriculture (2007); Nordhaus \& Boyer, supra note 5, at 91; David Anthoff et al., Equity Weighting and the Marginal Costs of Climate Change (Fondazione Eni Enrico Mattei Working Paper No. 43, 2007), available at http://papers.ssm.com/sol3/ papers.cfm?abstract_id=983032. 
far more to lose than others from, say, a 2.5 degrees Celsius increase in average temperature, while other nations are likely to be net gainers from such warming. ${ }^{41}$ Under prominent projections, India and African nations are especially vulnerable, and the United States and China have significantly less to lose. Because of increases in agricultural productivity, Russia might even gain. ${ }^{42}$ Here again we might consider both aggregate and per capita effects. Suppose that the mitigation benefits of the treaty produce benefits of $\$ 2000$ for one state and $\$ 0$ for the other state, or alternatively $\$ 1000$ for both states. ${ }^{43}$ In the first case, if the benefits accrue to Rich State, then each of its few citizens would receive a benefit of $\$ 400$; if the benefits accrue to Poor State, then each of its many citizens would receive a benefit of $\$ 100$. In the second case, each Rich State citizen would receive benefits worth $\$ 200$ and each Poor State citizen would receive benefits of $\$ 50$. Table 8 summarizes the discussion so far:

\section{Table 8: Distributive Effects of Permit Allocation Schemes}

\begin{tabular}{|c|c|c|c|c|c|}
\hline \multirow[b]{2}{*}{ System } & \multirow{2}{*}{$\begin{array}{l}\text { Permits } \\
\text { (Rich/ } \\
\text { Poor) }\end{array}$} & \multirow{2}{*}{$\begin{array}{c}\text { Aggregate } \\
\text { Revenue }\end{array}$} & \multicolumn{3}{|c|}{ Aggregate Net Benefits } \\
\hline & & & $\begin{array}{l}\text { R: } \$ 2000 \\
\text { P: } \quad \$ 0\end{array}$ & $\begin{array}{l}\text { R: } \$ 0 \\
\text { P: } \$ 2000\end{array}$ & $\begin{array}{l}\text { R: } \$ 1000 \\
\text { P. } \$ 1000\end{array}$ \\
\hline Status quo & $100 / 20$ & $1000 / 200$ & $3000 / 200$ & $1000 / 2200$ & $2000 / 1200$ \\
\hline Per nation & $60 / 60$ & $600 / 600$ & $2600 / 800$ & $600 / 2600$ & $1600 / 1600$ \\
\hline Per capita & $24 / 96$ & $240 / 960$ & $2240 / 960$ & $240 / 2960$ & $1240 / 1960$ \\
\hline Redistrib. & $0 / 120$ & $0 / 1200$ & $2000 / 1200$ & $0 / 3200$ & $1000 / 2200$ \\
\hline
\end{tabular}

\begin{tabular}{|c|c|c|c|c|c|}
\hline \multirow[b]{2}{*}{ System } & \multirow{2}{*}{$\begin{array}{c}\text { Per Capita } \\
\text { Permits } \\
\text { (Rich/ } \\
\text { Poor) }\end{array}$} & \multirow{2}{*}{$\begin{array}{c}\text { Per } \\
\text { Capita } \\
\text { Revenue }\end{array}$} & \multicolumn{3}{|c|}{ Per Capita Net Benefits } \\
\hline & & & $\begin{array}{l}\mathrm{R}: \quad \$ 400 \\
\mathrm{P}: \quad \$ 0\end{array}$ & $\begin{array}{l}\text { R: } \$ 0 \\
\text { P: } \$ 100\end{array}$ & $\begin{array}{l}\text { R: } \$ 200 \\
\text { P: } \quad \$ 50\end{array}$ \\
\hline Status quo & $20 / 1$ & $200 / 10$ & $600 / 10$ & $200 / 110$ & $400 / 60$ \\
\hline Per nation & $12 / 3$ & $120 / 30$ & $520 / 30$ & $120 / 130$ & $320 / 80$ \\
\hline Per capita & $4.8 / 4.8$ & $48 / 48$ & $448 / 48$ & $48 / 148$ & $248 / 98$ \\
\hline Redistrib. & $0 / 6$ & $0 / 60$ & $400 / 60$ & $0 / 160$ & $200 / 110$ \\
\hline
\end{tabular}

41. For an overview, see Eric A. Posner \& Cass R. Sunstein, Climate Change Justice, 96 GEO. L.J. 1565 (2008).

42. Cline, supra note 40, at 18; NoRdhaus \& Boyer, supra note 5 , at 91 .

43. A related point is that the cost of adjusting to the implicit carbon tax may vary across countries. Some countries have more abundant sources of clean energy, and some countries have industries that can more cheaply switch to alternative sources of energy. For a discussion in the context of the differential effects of per capita and historical approaches, see Joseph E. Aldy, Divergence in State-Level Per Capita Carbon Dioxide Emissions, 83 LANd Econ. 353 (2007). 
The first panel of Table 8 displays aggregate figures; the second panel displays per capita figures. The first figure in each cell displays Rich State's (or Rich State citizens') gain; the second figure does the same for Poor State. The Permit Distribution column displays the distribution of permits, as depicted in Table 7. The Aggregate Revenue column multiplies these numbers by ten in order to produce revenues from the sale of permits. The final three columns display the net treaty benefits (revenue plus climate benefits) under the three different assumptions about the differential impacts on the climate of an effective climate treaty. The cells with bold figures show outcomes that are most nearly equal for the two states.

One can immediately see that there is a large difference between equalizing revenue (Column 3 ) and equalizing the net benefits of the treaty (Columns 4-6). Focusing on per capita effects (Panel 2), we can see that the per capita approach equalizes revenues, but it does not equalize treaty benefits under any of the three assumptions, relative to the other approaches. Indeed, equalization of revenues can occur amidst gross disparities in treaty benefits-a point that raises serious questions about the idea that per capita distributions are fair.

III

\section{The Per Capita Approach in PrInCIPLe}

We now turn to the arguments on behalf of the per capita approach. We begin with welfarism, showing that that the per capita approach runs into serious objections from that perspective. We also suggest that from the standpoint of fairness, the per capita approach is much less attractive than it initially seems.

In discussions about climate treaties, defenders of the per capita approach argue that it is fairer than likely alternatives, such as the status quo approach. ${ }^{44}$ This argument is especially prominent in the developing world, where critics ask: Why should wealthy nations be given an entitlement to their existing emissions rights? ${ }^{45}$ This question seems to be one of fairness, to which we will turn in due course. But the question can also be translated into a plausible welfarist argument, to the effect that the per capita approach is more likely to increase social welfare than any imaginable alternative. It makes sense to begin with the welfarist argument, which is in some ways more tractable, and which will illuminate the fairness questions as well.

44. See supra note 6; e.g., SiNGER, supra note 6, at 35.

45. See, e.g., VANDERHEIDEN, supra note 6, at 226-39; Altamirano-Cabrera \& Finus, supra note 6, at 32; Sagar, supra note 6. 


\section{A. From a Welfarist Perspective}

\section{The case for the per capita approach}

Welfarists care about two things: maximizing the size of the pie and distributing it equally. The larger the pie, the more is available for everyone to consume; all else being equal, welfare should rise with consumption. ${ }^{46}$ At the same time, most welfarists believe that the welfare, or utility, obtained from an additional good declines. ${ }^{47}$ For instance, if you have zero apples, you would be willing to pay a lot for one apple. If you have ten apples, however, you would be willing to pay much less, or as little as zero, for an eleventh. Thus, if the entire pie is given to one person, social welfare would not be maximized. Ideally, the pie should be maximized, and then it should be divided evenly among all members of society. This ideal situation assumes no disincentive effects, which might decrease the size of the pie. We can easily see that if disincentive effects are small, welfarists would advocate redistribution of resources from wealthy nations to poor nations, or at least from wealthy people in both wealthy and poor nations to poor people in wealthy and poor nations. ${ }^{48}$

With respect to maximizing the size of the pie, we observed in Part II that the per capita approach is no less ex post efficient than any other approach. The reason is that the climate treaty advances ex post efficiency by giving individuals and governments incentives to minimize their emissions of greenhouse gases. Optimal incentives will depend on the quantity of permits, but not how they are distributed. As long as decision makers choose the right quantity, the size of the pie will be maximized. Efficiency, in this crucial sense, is not at stake in the choice among the four approaches.

Thus, the welfare effects of different schemes depend mainly on their distributional effects; other things being equal, distribution to those who are poor will increase welfare. ${ }^{49}$ The per capita approach might well seem to have attractive distributional effects and for that reason attractive welfare effects. To the extent that more populous countries tend to be poorer, the per capita approach will help poor people. Furthermore, under the theory that poor people have the highest marginal utility for a dollar, helping poor people will

46. We put to one side some prominent puzzles about the relationship between happiness and income. See Robert H. Frank, Luxury Fever (1999) (suggesting that relative wealth matters, not absolute wealth); P. Richard G. LAYARD, HAPPINESS (2005) (exploring ambiguous relationship between wealth and happiness).

47. See Matthew D. Adler \& Eric A. Posner, New Foundations of Cost-Benefit ANALYSIS (2005). Note that this approach assumes that interpersonal comparisons of utility are possible. On that issue, see $i d$; INTERPERsonal Comparisons of WELl-BEING (Jon Elster \& John E. Roemer eds., 1991).

48. See, e.g., SINGER, supra note 6; Eric A. Posner, International Law: A Welfarist Approach, 73 U. CHI. L. Rev. 487 (2006).

49. There is another type of efficiency at stake, which we call "ex ante efficiency." We will discuss this issue below. 
maximize global welfare.

Certainly compared to the status quo approach, per capita allocations seem supportable on welfarist grounds; at first glance, a per capita system seems to be the right way to proceed. The examples of the United States on the one hand, and China and India on the other, are highly salient, because the former is rich and the latter two are poor by comparison. To the extent that the per capita approach would require the United States to give, in essence, hundreds of billions of dollars to China and India, it might seem desirable on welfarist grounds.

At the outset, of course, there is a serious complicating factor. Emissions reductions will help future poor people, not present poor people. It is not obvious that policymakers in wealthy nations should attempt to help future poor people, who are likely to be far less poor than present poor people. ${ }^{50}$ If the goal is redistributive, current poor people almost certainly deserve priority. This point greatly complicates the claim that emissions reductions are justified on redistributive grounds. Note, however, that we are speaking of emissions rights, not emissions reductions, and emissions rights will benefit people who are now living. For this reason, the redistributive argument, grounded in welfarist considerations, has considerable intuitive appeal.

\section{Objections and concerns}

We have said that welfarists care about equal distribution, believing that money has diminishing marginal utility. From their perspective, the per capita approach has three serious defects.

First and most fundamentally, the per capita approach is attractive to a welfarist only insofar as more populous states tend to be poorer. Not all heavily populated states are poor, however, and not all lightly populated states are rich. For instance, the United States is both large and rich, with a population of 301 million and per capita GDP of $\$ 46,000$. Bhutan, on the other hand, is both small and poor, with a population of two million and a per capita GDP of $\$ 1,400$. $^{51}$ The per capita approach, then, seems to be a crude and even arbitrary way to redistribute wealth, especially compared to the pure redistributive approach, which gives few or no permits to rich states and all or most of the permits to poor states, regardless of population size. We assumed away this problem in our example in Part II because we stipulated that Poor State was both bigger and (as befits its name) poorer. But that assumption is unrealistic.

Indeed, the relationship between population and wealth turns out to be essentially zero. For a demonstration, consider Figure 1.

50. See Posner \& Sunstein, supra note 41.

51. We take these figures from the CIA World Factbook, available at https://www.cia.gov/library/publications/the-world-factbook/. 


\section{Figure 1: Relationship Between Population and Per Capita Wealth ${ }^{52}$}

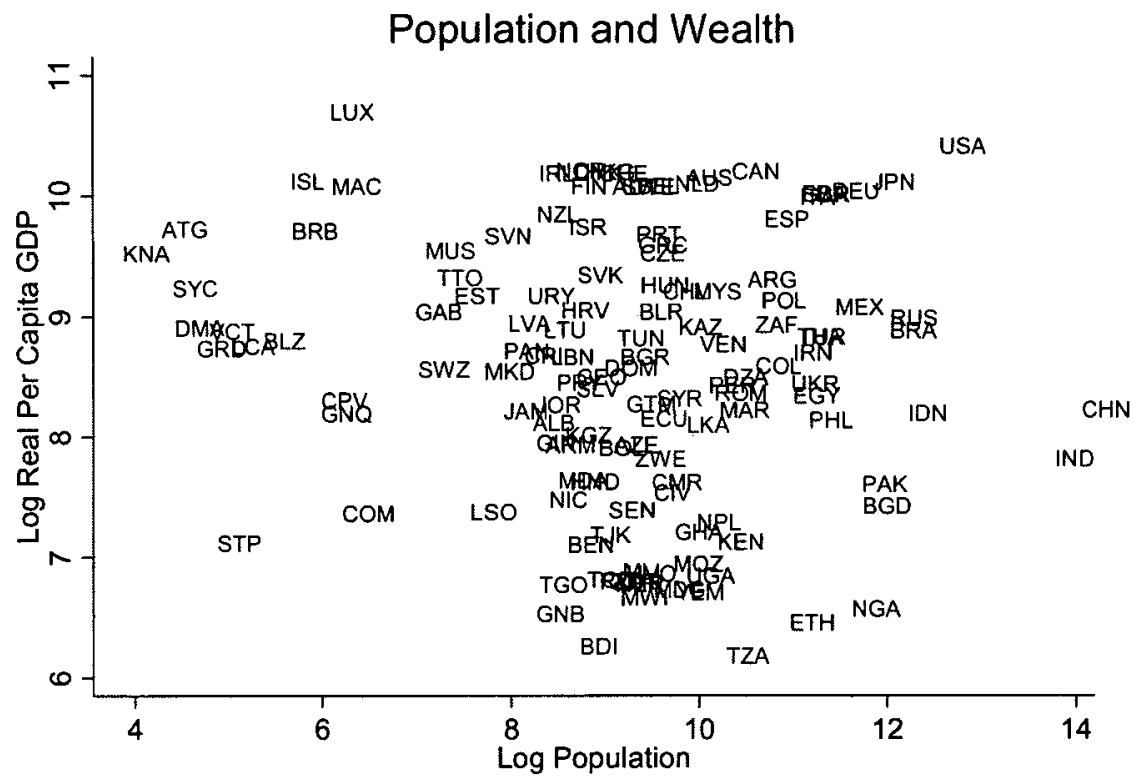

Clearly, there are rich small states (upper left), and poor big states (lower right), and everything in between. As Figure 1 shows, there is no statistically significant correlation between population and per capita GDP.

Second, the permits-in the scheme that we describe in Part II-are distributed to both greenhouse gas winners and losers. Some poor states will become far poorer as a result of climate change; other poor states are less vulnerable. ${ }^{53}$ Similarly, some rich states will face serious adverse economic effects from climate change; other rich states are less vulnerable. ${ }^{54}$ Some states

52. The figure shows the natural logs of per capita GDP and population averaged over the years 1980 to 2000 . Taking the natural $\log$ of the variables makes the data points easier to see in a manageable figure. The correlation coefficient between per capita GDP and population is -0.036 and is not statistically significant. The data are taken from ALAN Heston ET AL., CENTER FOR International Comparisons of Production, Income, and Prices at the University of Pennsylvania, Penn World Table Version 6.2 (2006), available at http://pwt.econ.upenn.edu/php_site/pwt62/pwt62_form.php.

53. Thus, for example, India is far more vulnerable than is China. See NordHaus \& Boyer, supra note 5, at 91; Climate Change Risk Report, supra note 40, at 17. Among the most vulnerable nations are Somalia, Burundi, Yemen, Nigeria, and Afghanistan; other poor nations, including Thailand, Colombia, Indonesia, and El Salvador, are significantly less vulnerable. Climate Change Risk Report, supra note 40, at 17.

54. Thus, for example, the United States is far less vulnerable than many nations in Europe. NORdHaus \& BOYER, supra note 5, at 91 , and Canada is less vulnerable than the Netherlands, Austria, and Gemany, Climate Change Risk RePort, supra note 40, at 17. 
may even be net gainers from climate change. ${ }^{55}$ If distribution is our concern, why should two highly populated poor nations receive the same number of permits from a program from which one nation would gain a lot and another a little - or from which one would gain a lot and another would actually lose? Ideally, permits should be distributed in light of these consequences, but the per capita approach fails to take them into account.

Third, the permits are allocated to the governments of poor states, not to the citizens of poor states. This distinction matters because nearly all poor states have a class of wealthy elites, and these wealthy elites usually control the government, or at least have considerable influence over it. Given that the governments in these states already are unenthusiastic about redistributing wealth from the elites to the poor, it is questionable that they will use the wealth generated by the permit scheme to help the poor. They may well prefer to help the rich. We will return to this problem in Part IV.

The intuitive attractiveness of the per capita approach depends on seeing it in isolation from all of the effects of a climate treaty. Once we take these various factors into account, the per capita approach appears far less attractive, and on plausible assumptions, indefensible from the standpoint of the very rationales that most justify it at first sight.

We agree that as a matter of actual practice, these defects are not necessarily fatal to the per capita approach. Everything depends on the alternatives. One might argue in response that while the per capita approach is not ideal, it is still superior to a system that is its most likely alternative-one that uses status quo energy consumption as the baseline and thus favors people living in wealthy and wasteful countries. Perhaps this response is correct. But it must acknowledge the underlying problem, which is that the per capita system is only indirectly connected to the underlying normative goal-indeed, so indirectly that it is conceivable in principle that it has worse distributive effects than the status quo approach.

A welfarist should favor redistribution to the world's poor to the extent that doing so is feasible and does not excessively reduce aggregate global welfare. But there is no reason to think that the per capita approach to climate regulation is the right way to redistribute wealth and thus to increase global welfare. From a welfarist perspective, a sensible redistributive policy would follow these general principles: redistribute all resources rather than shares of the atmosphere's capacity to absorb greenhouse gases; redistribute resources to poor people rather than to poor nations; and redistribute to poor nations rather than to populous nations. If redistribution is to occur in the specific context of a climate treaty, the redistributive approach, sketched in Part II, would be much better than the per capita approach.

55. See NoRdHAus \& Boyer, supra note 5, at 91 (projecting, for example, significant net gains for Russia). 


\section{More on welfare: ex ante efficiency}

Arguments in favor of per capita distribution have, so far, focused on what we have called ex post efficiency effects, and neglected the possible ex ante effects of the distribution scheme. We discussed the ex post effects above, and showed that the ex post efficiency effects of the different schemes are identical (or nearly so). The same cannot be said for ex ante efficiency. From that standpoint, the effects are different, and the per capita approach has some significant drawbacks.

To understand the difference between ex post and ex ante efficiency, recall that any tax or cap-and-trade system that requires firms or individuals to internalize the social cost of their greenhouse gas emissions is efficient, in the sense that under these schemes firms and individuals will use energy only when the social benefits (including their own profits or consumption) are greater than the social costs (including the costs to the climate). We call this type of efficiency "ex post" because it addresses an existing problem, though, to be sure, one that will continue into the future.

On the other hand, the ex ante effect of a climate treaty refers to its effect on future programs, including those that have nothing to do with greenhouse gases. Any treaty will establish a precedent on which states will rely, at least in part, as they negotiate additional treaties in the future: treaties that will be needed to handle such global problems as terrorism, cross-border transmission of diseases, and nation-building efforts in failed states. For example, if the per capita approach is used for a climate treaty, then it might suggest itself as a basis for allocating the costs of an anti-terrorism treaty.

Similar assumptions are routinely made about domestic programs. For example, the U.S. government could alleviate poverty by announcing one day that it will take most of the wealth of rich Americans and give it to poor Americans. Such a program is not inefficient in the ex post sense: given that the rich have already accumulated their wealth, they cannot retroactively be deterred from working hard. The program will have prospective effect, however. Even if announced as a one-time event, people will assume that if the government implements such a program today, it might do so again tomorrow. This assumption will influence their ex ante behavior, reducing their incentive to work and save. ${ }^{56}$

56. These effects are addressed in the law and economics literature on legal transitions, or changes in the law. See, e.g., Louis Kaplow, An Economic Analysis of Legal Transitions, 99 HARV. L. REv. 509 (1986). This literature focuses on domestic law, where it is clearer than in the international context that a government that adopts certain policies or practices toward legal transitions - compensating or grandfathering those injured by the transition, for example-will affect the incentives of people to anticipate legal change. We extend this literature to the international setting; there is no reason to think that the differences in settings should affect the analysis. The transitions literature ignores what we have called "ex post efficiency," instead assuming that whatever legal change that is introduced is dictated by efficiency. The environmental literature, by contrast, focuses on ex post efficiency (for example, the choice 
Suppose, then, that a climate treaty based on the per capita approach established a precedent. How might such a precedent influence behavior, compared to the status quo approach? It would create two perverse incentives: encouraging population growth and discouraging economic growth.

First, the per capita approach would establish that the most highly populated states would obtain the greatest benefits from international cooperation. Governments would be rewarded for pursuing fertility policies that maximize the size of the population. To see why, consider a state with population $X$ and another state with population $2 X$. Suppose that a future treaty would limit the spread of infectious diseases, creating benefits of $Y$. The states would need to negotiate a division of the surplus. With the per capita principle in place, the state with the larger population would be able to claim a larger portion of the surplus.

From a redistributive perspective, this result might seem fair (unless the people in the larger state are richer), but in terms of prospective incentives, states would have one more reason to grow and to avoid shrinking. This incentive would be especially perverse from the perspective of climate change because more people will consume more of the earth's resources, though the exact effect of population growth is complex. On the other side, the climate treaty, to the extent that it fixes the initial number of permits, will also restrain growth. Given the relatively low amount of international cooperation, and hence the relatively low amount of treaty-making, one might doubt that the incentive to expand population in order to obtain future treaty advantages is particularly strong. To evaluate the extent of the problem we need to know the magnitude and not merely the direction of the incentive effect. Still, this problem is a cost of the per capita approach that should be kept in mind. ${ }^{57}$

Second, to the extent that it favors poorer countries (and that is its only normatively attractive feature), the per capita approach would establish that poorer states would obtain the greatest benefits from international cooperation. In the abstract this seems desirable, but governments that adopt policies that promote economic growth would be penalized by this principle. Most rich states get wealthy because they have good institutions, not because they are lucky enough to have natural resources. ${ }^{58}$ Citizens invest in creating and

between permits systems and taxes) and generally, although not always, ignores ex ante issues. For a discussion, see Jonathan R. Nash, Allocation and Uncertainty: Strategic Responses to Environmental Grandfathering 18-22 (Jan. 24, 2008) (unpublished manuscript) available at http://law.bepress.com/cgi/viewcontent.cgi?article=2650\& context=alea.

57. These perverse population incentives have long been recognized. However, many scholars seem to think that these incentives can be eliminated as long as allocations of permits are made with reference to a past distribution of population rather than to future populations. See, e.g., SingER, supra note 6 , at 36 . Such an approach would not address the perverse incentives of the precedent for future treaties, when high-population states will invoke the climate treaty as a basis for demanding more favorable treatment.

58. In fact, development economists have gone so far as to identify a "resource curse": countries with valuable natural resources often do worse than those that lack them. See generally 
maintaining good institutions because good institutions deliver wealth and other benefits. A redistributive principle such as the per capita approach implicitly punishes states that do well economically, while rewarding states that do poorly.

The goal of development aid over the past decades was precisely the opposite: to give governments of developing countries an incentive to adopt sound economic policies that promote growth. Because of fears that foreign aid would provide incentives not to grow, donors made concerted efforts to condition aid on the adoption of sensible growth policies. ${ }^{59}$ The per capita approach-and indeed, any redistributive principle-is at war with the lessons of development policy, and would weaken the pro-growth incentives that are currently given to developing states.

What system, then, is optimal for ex ante efficiency? The ideal system would give states an incentive to identify global problems in advance and negotiate treaties to solve them without affecting their incentives to control their populations, invest in institutions, and so forth. Our interest in that ideal system is connected with International Paretianism; recall that this principle means that states are unlikely to enter into treaties unless they believe that they will not be made worse off as a result. ${ }^{60}$

But treaties that solve problems generate surpluses beyond the amount necessary to make states indifferent between entering and not entering a treaty. What should be done with the surplus? It is tempting to think that one could distribute the surplus without affecting incentives ex ante, but this is highly implausible. If one could, then one would probably want to distribute the surplus to the poorest countries rather than on a per capita basis, which, as we argue, is morally arbitrary.

From an ex ante efficiency perspective, the best use of the surplus would be to reward the states that had taken steps in advance of the treaty to abate greenhouse gases. ${ }^{61}$ These states would probably be the European states that accepted binding emissions reductions under the Kyoto Protocol, though there are complexities here, since not all European states accepted meaningful reductions and others were simply taking advantage of independent

Richard M. Auty, Sustaining Development in Mineral Economies (1993).

59. See David Dollar \& Victoria Levin, The Increasing Selectivity of Foreign Aid, 19842003, 34 WORLD DEv. 2034, 2034-36 (2006) (describing this view as an emerging international consensus).

60. The Pareto principle in economics refers to the idea that an allocation of resources makes at least one person better off and no one worse off compared to some other allocation. We do not attempt to specify here the ingredients of a state's judgments about what would make it better off or worse off; we agree that some states have altruistic goals and so include, in their own welfare, the welfare of those in other states.

61. Hence the scholarly support for banking systems under which any future climate treaty would reward states that make abatement efforts prior to treaty ratification. See, e.g., Kinzig \& Kammen, supra note 6 . For a discussion of the use of this principle in domestic environmental law, see Nash, supra note 56. 
technological and demographic changes in their country. ${ }^{62}$

The larger point is that such a distribution would establish a precedent to the effect that when a global problem exists, states that respond quickly and in advance of a treaty will not be penalized. With this principle in place, states would be more likely to act quickly and to negotiate a treaty regime rather than drag their feet. For example, if states ever need to enter a new treaty that regulates cybercrime, they would know that first movers that have implemented controls that reduce dangers to other states would not be penalized and would even be rewarded in some way.

From the standpoint of ex ante efficiency, the per capita approach has serious drawbacks, even when compared with the seemingly unattractive status quo approach. As we have indicated, these drawbacks cannot be evaluated without knowing the magnitude of the effects. If, for example, a climate change agreement had small consequences for population growth, and had little effect on incentives in the context of other international agreements, the drawbacks would not be a substantial concern. Our point is only that these drawbacks must be investigated in order to obtain a full account of the welfare effects of the per capita approach.

\section{B. From a Fairness Perspective}

Ideas about fairness play a significant role in debates over the proper approach to climate change. ${ }^{63}$ Fairness can be specified in multiple different ways. We venture three specifications here in an effort to see whether the per capita approach can be defended on fairness grounds.

\section{Fairness and the veil of ignorance}

Many scholars reject the idea that questions of global justice should be approached in welfarist terms. ${ }^{64}$ In their view, the goal is not to promote aggregate social welfare; it is instead to do what fairness requires. Arguments of this kind often posit a veil of ignorance, or "original position," from which the principles governing allocations of resources might be chosen. ${ }^{65}$ In the standard version of this argument, people behind the veil do not know various circumstances of their lives; they do not know their place in society, or even their natural assets such as intelligence and strength. ${ }^{66}$ The central claim is that

62. See Kathryn Harrison \& Lisa McIntosh Sundstrom, The Comparative Politics of Climate Change, 7 Global EnvtL. Pol. 1 (2007) (describing the differential effects of the Kyoto Protocol on European countries).

63. Fairness concerns are the principal ones in the essays cited supra in note 6. For the most recent comprehensive discussion, see VANDERHEIDEN, supra note 6.

64. See Martha Craven Nussbaum, Frontiers of Justice (2006); Thomas Winfried Menko Pogge, Realizing Rawls 211-80 (1989).

65. See John Rawls, A Theory of Justice 118-23 (rev. ed. 1999).

66. Id. at 118 . 
principles that would be chosen behind the veil qualify as fair, because they ensure that outcomes are not a product of factors or considerations that are irrelevant from the moral point of view. ${ }^{67}$

Scholars who are attracted to this approach may also want to suppose that choosers are made ignorant of the nation in which they might find themselves. ${ }^{68}$ If deprived of that information, what distributive principles would they select? It is possible that in the international context, as in the domestic one, they would select welfarist principles. Perhaps people would choose to maximize overall welfare, if placed behind the veil. ${ }^{69}$ But it is also possible that people behind the veil would take particular care to protect the least well-off, perhaps through a version of Rawls' difference principle, which permits inequalities only to the extent that they operate to the advantage of the least advantaged. ${ }^{70}$ There is a vigorous debate over the application of that principle or imaginable variations to the international domain. ${ }^{71}$ Rawls himself believed that there would be real difficulties in adapting the difference principle to the international context. ${ }^{72}$ But even in that context, the idea of a veil of ignorance may turn out to be helpful. ${ }^{73}$ Some philosophers believe that the best approach specifies a floor constraint, ensuring that everyone is elevated above some threshold. ${ }^{74}$ Even without a floor constraint, international agreements might be developed with close attention to the veil of ignorance, which may well require a great deal of redistribution across national boundaries. ${ }^{75}$

We need not pause over the philosophical complexities here. ${ }^{76}$ The basic point is that welfarism is rejected by many people who believe that severe deprivation for some cannot be justified by large welfare benefits for many. Furthermore, fairness is often taken to require attention to those who face such deprivation, whatever the welfarist calculus suggests. ${ }^{77}$

Consider a common-sense specification of this claim, adapted to the

67. Id.

68. See PoGgE, supra note 64, at 211-236.

69. Cf. John C. Harsanyi, Can the Maximin Principle Serve as a Basis for Morality, 69 Amer. Pol. Sci. Rev. 594 (1975) (arguing that people would choose to maximize average utility, behind the veil of ignorance).

70. See RAWLS, supra note 65 at 65-70.

71. For varying perspectives, see NuSSBAUM, supra note 64, at 273-324; PoGGE, supra note 64.

72. See John Rawls, The Law of Peoples (1999).

73. See id.; PogGe, supra note 64.

74. Norman Frohlich \& Joe A. Oppenheimer, Choosing Justice (1992) (finding that people would choose to maximize utility with a floor constraint, behind an experimental effort to mimic the veil of ignorance); cf. NussBaum, supra note 64, at 291-95 (discussing idea of threshold).

75. See NussBaum, supra note 64.

76. For a detailed treatment, see id. at 291-324.

77. Welfarism will also be rejected by those who believe that principles of justice do not extend across borders. See, e.g., RAwLs, supra note 65 at 7; Thomas Nagel, The Problem of Global Justice, 33 PhIL. \& PUB. AfF. 113 (2005). 
climate change problem. Some nations are much richer than others, in a way that violates the requirements of justice. ${ }^{78}$ Perversely, the status quo approach creates a kind of entitlement to the continuation of practices that violate those requirements. No such entitlement can be defended. Even if corrective justice does not require high-emissions states to compensate those nations that are at special risk, ${ }^{79}$ a climate change agreement would be unacceptably unfair if it made development more difficult for poor nations. Such an agreement would be especially unfair because development is designed to remove citizens in poor nations from difficult conditions, and to allow poor nations to achieve something closer to parity with wealthy nations. A per capita approach would be the most fair under this analysis, because it counts every citizen as no less and no more than one, in a way that respects the moral irrelevance of national boundaries. $^{80}$

We do not intend to challenge these general points about fairness here. Rather, our basic claim is that if these points are meant to provide a defense of the per capita approach, they run into serious difficulties. The reason is that the central objections to the welfarist argument rematerialize when fairness, understood in the ways sketched above, is our guide. First, to the extent that some of the most populous states are wealthy, the per capita approach is not fair at all since it has some of the same vices as the status quo approach. Second, per capita allocations have the disadvantage of giving large numbers of permits to highly populated nations that have relatively little to lose from climate change. Finally, it remains true that permits are allocated to the governments of poor states, not to the citizens of poor states, and allocations to such governments may not help those who are most in need.

\section{The atmosphere as common property}

There is another type of fairness argument that has been made about emissions rights. The atmosphere, with its beneficial carbon-absorbing characteristics, is common property, belonging to everyone in the world. ${ }^{81} \mathrm{~A}$ climate treaty would close this commons, converting it into private property. It is only fair to distribute the parcels of property to the former users of the commons, namely, everyone in the world, on a per capita basis.

One might draw an analogy to minerals discovered in the sea bed under the high seas, which are outside the sovereignty of any country. The Convention on the Law of the Sea provides that revenues from exploitation of

78. See NussBaum, supra note 64.

79. See Posner \& Sunstein, supra note 41

80. See, e.g., Altamirano-Cabrera \& Finus, supra note 6 (arguing for one person, one vote analogy); Paul Baer et al., Equity and Greenhouse Gas Responsibility, 289 SCIENCE 2287 (2000) (arguing that the per capita approach is justified by the principle of "equal rights").

81. See, e.g., Grubb et al., supra note 18, at 318-19; Ott \& Sachs, supra note 6, at 168. 
these minerals should be distributed "equitably." ${ }^{82}$ But the analogy is at best incomplete and in fact reveals the limits of the common property argument. A climate treaty, like a treaty allowing for the exploitation of minerals, has two effects of present interest. First, both treaties generate revenues: for permit sellers, in the climate case, and for mining companies, in the mineral case. Second, both treaties generate benefits for consumers: people benefit from abatement of climate change, and people benefit from the lower price of, say, oil. Because virtually everyone benefits from lower oil prices, the effect is spread around the world. Thus, the only remaining question in the case of the mineral treaty is how to distribute revenues fairly. In the climate case, the climate effects are extremely variable-hurting some people very badly, having no effect on others, and benefiting still others. ${ }^{83}$ From the standpoint of fairness, it would be strange to ignore these harmful effects while considering only the revenue effects. The analogy to common property is not helpful; it distracts from the relevant question, which is the distribution of all treaty effects across the world's population.

\section{Treatment of the similarly situated}

Suppose that we understand the idea of fairness not in redistributive terms, but as a requirement that similarly situated people be treated similarly. As we saw above, the per capita approach is not attentive to the differential distributional effects of climate change and abatement costs, but in effect gives every person the same asset. From one perspective, the main objection to this feature of the per capita system is that it means that wealth does not necessarily go to the poor. But holding wealth constant, it might also seem unfair that frugal individuals who have produced low levels of greenhouse gas emissions receive the same payout as profligates who have produced high levels. And it might also seem unfair that people who are most hurt by climate change receive the same payout as those who are least hurt (or even benefited) by climate change. Finally, we might think people who are most hurt by the abatement efforts mandated by the climate treaty should receive some kind of compensation. Consider, for example, low-income workers who commute to work and must pay higher bus fares or fuel prices. One might argue that fairness requires that these people receive permits, so that they do not bear a disproportionate cost of the treaty regime.

82. See Law of the Sea Convention, supra note 20.

83. One might argue that minerals extracted pursuant to a treaty will have differential effects, mainly benefiting those who already have a high demand for the mineral. We suspect that, in practice, the drafters of the Law of the Sea Convention anticipated that the overall effect of a mineral discovery on worldwide prices will be slight; but to the extent that this is not the case, then those differential effects should be taken into account in order to determine equitable distribution. 


\section{The Per Capita Approach as an Incompletely Theorized Agreement}

We have seen that in principle, significant global redistribution is plausibly justified by considerations of both welfare and fairness. But in practice, such redistribution does not occur. For example, there is no evidence that the United States wants to transfer hundreds of billions of dollars to poor people in India or China rather than the tens of millions of dollars that are currently appropriated. ${ }^{84}$ In these circumstances, defenders of per capita allocations might argue that their approach has three virtues. First, the per capita approach might be feasible even if a preferred form of redistribution is not. Second, such an approach might provide the basis for a kind of incompletely theorized agreement among those who have different moral commitments, or who are unsure about the appropriate moral commitments in the international domain. Third, per capita allocation might, because of its simplicity and attractiveness, provide a plausible focal point for political action, a basis for an international agreement to which many nations could subscribe, even if it would be fanciful to suggest that wealthy nations might sign an international agreement in which they agree to transfer hundreds of billions of dollars to poor nations. ${ }^{85}$

We will return to feasibility in the next Section. For the moment, let us add a further consideration. Wealthy nations, including the United States, face serious risks from climate change, and to reduce those risks, they need international cooperation. Indeed, it is increasingly clear that they need cooperation from the developing world. To obtain that cooperation, they might well be willing to expend resources that they would not give in foreign aid. Consider some illustrative numbers. ${ }^{86}$ Suppose that the United States would lose 3 percent in annual GDP from "business as usual," in the form of no international agreement at all. Suppose that the ideal international agreement would cost the United States 0.5 percent in annual GDP, while reducing the 3 percent loss to a 1 percent loss, for a net gain of 1.5 percent. Suppose, however, that developing countries reject this agreement, on the ground that its costs are too high and its benefits too low, and that developing nations seek either an agreement with different content or with some kind of financial assistance. The different content might mean a worse cost-benefit ratio for the United States. On the stipulated numbers, the United States should be willing to pay up to 1.5 percent of annual GDP to obtain the benefits of an international agreement.

84. The United States awarded $\$ 23$ million in aid to China for democracy, human rights, and rule of law programs, and $\$ 125$ million in aid to India in 2006. See ThOMAS LUM, CRS Report for Congress, U.S. Foreign Aid to East and South Asia: Selected Recipients 14, 29 (2007), available at $\mathrm{http}: / / \mathrm{www}$. fas.org/sgp/crs/row/RL31362.pdf.

85. See, e.g., Grubb et al., supra note 18 , at 319.

86. For a study suggesting that the numbers here are in a plausible general ballpark, see Dale W. Jorgenson et al., Pew Center on Global Climate Change, U.S. Market CONSEQuences of Global Climate Change (2004), available at http://www.pewclimate.org/ global-warming-in-depth/all_reports/marketconsequences. 
And indeed, there is evidence that wealthy nations are willing to pay nontrivial amounts to poorer ones in return for their cooperation in international agreements. $^{87}$

Whatever its implications, this argument does not support a per capita approach at all. All that this argument says is that any climate agreement will create a surplus, and it will be necessary, and possibly very difficult, for nations to decide how to divide that surplus. If the United States would gain a great deal from a treaty, while a poor nation such as China would gain a lot less, it might be necessary for the United States to accept a smaller portion of the surplus than China obtains, even to gain less on a per capita basis than China does. Meanwhile, India might lose more than the United States does, and these bargaining dynamics might work out in the United States' favor as between these two states. In principle, relative wealth should matter to the distribution of the surplus. Whether on grounds of welfare or fairness, poor countries should be entitled to a significant share, perhaps through financial assistance or some kind of side payment. But there is no particular reason to think that the type of bargain that is welfare-maximizing, fair, or feasible should reflect relative population size rather than another factor such as relative size of economy or relative advantages from a climate treaty.

A similar point could be made about the possibility that the per capita approach could reflect an incompletely theorized agreement. Suppose that nations acknowledge that certain moral principles do, or should, guide international relations, but that they disagree about what those moral principles are $^{88}$ If one believes the rhetoric of governments, one can identify a set of standard moral arguments. Among developing nations, some argue that the rich world has obligations to the poor arising from the history of colonial exploitation. ${ }^{89}$ Others argue that rich nations have obligations arising from particular policies that they have adopted in the recent past and that continue in the present, such as unfair trade rules and the treatment of debt. ${ }^{90}$ Still others argue simply that resources that exist outside the sovereign territory of each state should be shared. ${ }^{91}$ Some rich nations are willing to acknowledge that they have an ethical obligation to provide aid to the very poorest people. Others say that they have an obligation to cooperate with poor nations, or at least not to interfere with them, but not necessarily to provide aid. ${ }^{92}$

87. See BARRETt, supra note 21, at 335-54 (2003) (discussing side-payments).

88. For a discussion of various possible moral positions, see NussbaUM, supra note 64 , at 273-324.

89. U.N. Hum. Rts. Council [UNHRC], Report of the Working Group on the Right to Development, ๆ 19, U.N. Doc. A/HRC/4/47 (Mar. 14, 2007).

90. Id. at I 18; see also Stephen Marks, The Human Right to Development: Between Rhetoric and Reality, 17 HARV. Hum. RTS. J. 137, $141-42$ (2004).

91. See, e.g., Law of the Sea Convention, supra note 20.

92. These acknowledgements can be found, in vague terms, in such documents as Declaration on the Right to Development, G.A. Res. 41/128, U.N. GAOR, 41 st Sess., 97 th plen. 
Observe that these different moral arguments have very different implications. Even among the poor nations, whose views seem consistent at first sight, one can detect radically different implications of the different arguments. If one focuses on colonial exploitation, then the major beneficiaries should be former colonies (including rich states like Taiwan), and the major payers should be former empires (including Great Britain, Russia, and Portugal but not so much the United States). Moreover, the idea of colonial exploitation suggests that former colonies should direct their claims at their former masters, not to the rich world as a whole. India's extra permits, for example, should come out of Great Britain's pocket. Similarly, if tariff policy is the source of complaints, one would need to determine which tariff policies were supported by whom, and which countries they harmed, which would be a highly complex and controversial process. And if tariff polices that have adverse effects on other nations (and what tariff policies do not have such effects?) should count, so should all other policies that have given rise to legitimate grievances. One would thus need to keep in mind the particular grievances that some poor countries have against other poor countries (India and Pakistan, Rwanda and Burundi), and allocate permits accordingly.

Even if the rich nations owe extra permits to poor nations, within the class of poor nations permits would have to be distributed unequally to account for current and past injustices. Generous treatment, such as many rich nations' contributions to the victims of the tsunami in South Asia in 2004, would need to be subtracted, lest rich nations hoard their generous impulses as offsets to permit regimes. And all of this would need to be done in a manner that respected the views of those who care about redistribution on grounds solely of redistributive justice or welfare maximization. ${ }^{93}$

Within countries, moral disagreement of this type does not necessarily preclude policy-making, even on issues that divide people sharply along moral lines. Typically, the policy that emerges reflects an incompletely theorized agreement. ${ }^{94}$ People with different moral views can agree on a policy consistent with their different interests and different moral views, while bracketing their remaining conflicts or putting them off until a later time. For example, in the United States some people support affirmative action as a way to overcome past injustices, while others defend it as a forward-looking policy for promoting certain social goals, such as stability. ${ }^{95}$ The moral views have

mtg., U.N. Doc. A/41/53 (Dec. 4, 1986), and World Conference on Human Rights, June 14-25, 1993, Vienna Declaration and Programme of Action, U.N. Doc. A/CONF.157/23 (July 12, 1993).

93. For an effort to derive a distribution system that takes into account historical behavior, see Sagar, supra note 6.

94. On such agreements in general, see Cass R. Sunstein, Legal Reasoning AND Political Conflict (1996). On the lack of concrete theoretical grounding for international agreements, see BARRETT, supra note 21.

95. See Kathleen M. Sullivan, Sins of Discrimination: Last Term's Affirmative Action Cases, 100 Harv. L. REv. 78 (1986). 
different implications for how affirmative action should be designed and how long it will last, but those holding these different views can sometimes agree enough to put their weight behind a program that furthers some of their goals but not others. Similarly, one might argue that the per capita approach could reflect an incompletely theorized agreement among nations and individuals with different but overlapping moral views about what nations owe each other.

This argument also is weak. None of the moral views described above would support the claim that greenhouse gas permits should be distributed according to population size, with the possible exception of the view that commons should be shared. But even that view does not clearly distinguish between per nation sharing and per capita sharing. If there is a common thread among these theories, it is the view that richer nations have an ethical obligation to aid or cooperate with poor nations. But as we have seen, poor nations and populous nations are not necessarily the same.

IV

\section{FEASIBILITY ISSUES WITH THE PER CAPITA APPROACH}

Thus far our focus has been on issues of principle. A general lesson has been that there are reasons for significant redistribution to poor people in poor nations on grounds of either welfare or fairness. In light of such justifications, the redistributive approach seems far better than the per capita approach, which seems in turn to be far better than the status quo approach. The main objection to the redistributive approach involves incentive effects. The question is whether the welfare loss from such effects outweighs the welfare gain from redistribution. It is entirely plausible to think that a climate change agreement that includes significant redistribution will be better, on welfarist grounds, than one that does not. But any climate change agreement must also be feasible, and the constraints of feasibility impose significant restrictions on the pursuit of ideals. The poignant irony is that insistence on the first-best outcome, as a matter of principle, may make the climate change problem intractable, in a way that could lead to disaster from the standpoint of the very nations that are poorest and most vulnerable. ${ }^{96}$

\section{A. State Consent and International Paretianism}

Any realistic approach to climate regulation will have to come about through changes in international law. Most serious discussion today focuses on a possible climate treaty because no nation can make a serious dent in anticipated warming on its own. ${ }^{97}$ The United Nations Framework Convention

96. India is the most obvious example here, because it is unusually vulnerable to damage from climate change and also most insistent on per capita allocations. On India's vulnerability, see NORDHAUS \& BOYER, supra note 5, at 91 .

97. See NordHaUs supra note 10; Posner \& Sunstein, supra note 41. 
on Climate Change of 1992 set the stage for negotiations that culminated in the Kyoto Protocol of $1997 .^{98}$ The treaty mandated that developed nations cut greenhouse gas emissions over a period of years, but imposed no emissions reductions obligations on developing nations. ${ }^{99}$ The United States refused to ratify the Kyoto Protocol, in part because the treaty obligated the United States to make quite significant emissions cuts, thereby imposing costs much greater, in terms of monetary expense, than those imposed on other nations. ${ }^{100}$ In the most recent round of negotiations at Bali in 2007, the United States agreed to resume negotiations, with an eye toward joining a new treaty that would provide for binding greenhouse gas emission abatement obligations a few years hence. $^{101}$

The difficulty of obtaining the consent of the United States to an international agreement illustrates an important point: because treaties require the consent of treaty partners, states must believe that by entering a treaty they are serving their national interests. Of course the idea of national interest can be specified in many different ways. But as a first approximation, nations primarily care about the welfare of their own citizens, not necessarily about the welfare of citizens of other countries. ${ }^{102}$ A workable climate treaty will have to be one that not only serves the interests of the United States, but also the interests of other major industrial nations, including developing countries such as China and Brazil. We have used the term International Paretianism to refer to this pragmatic constraint on treaty-making: a treaty is not possible unless it makes all its signatories better off.

It should be clear from the foregoing discussion that we reject International Paretianism in principle. From a welfarist perspective, a step such as genocide prevention might be justified even if its national benefits are exceeded by its national costs, so long as the global benefits exceed the global costs. Nor do we insist that International Paretianism is always a firm constraint on domestic judgments. It is imaginable, for example, that domestic forces will favor at least some degree of altruism, so that nations will take steps that promote global welfare without promoting domestic welfare. The only point is that domestic self-interest imposes a significant limitation on what is feasible, and that nations should not be expected to sign a climate change agreement from which they are large-scale net losers. China is not likely to sign an

98. Kyoto Protocol, supra note 3.

99. For valuable discussion, see SCOTt BarReTt, Why CoOperate? (2007).

100. See SUNSTEIN, supra note 4, at 91-93.

101. See Bali Action Plan, supra note 9.

102. The best evidence for this proposition is the pattern of foreign aid. Poor countries, understandably, do not provide foreign aid, but middle-income countries also do not seem to feel that they have a responsibility to help people living in poorer countries. Rich countries provide foreign aid but are not generous, and scholars have shown that much (but not all) foreign aid can be traced to specific strategic interests. See, e.g., Alberto Alesina \& David Dollar, Who Gives Foreign Aid to Whom and Why?, 5 J. ECON. GrowTH 33, 55-56 (2000). 
agreement that would cost it, on net, hundreds of billions of dollars each year; the same is true of the United States. An important question, then, is whether a proposed allocation of emissions rights will require one nation to give a great deal, in monetary terms, to others.

Even if nations care only about their economic well-being, they might well be willing to join a suitably designed climate treaty. Scientific and economic models indicate that, most likely, substantial cuts in greenhouse gas emissions will produce global benefits in excess of global costs. ${ }^{103}$ For purposes of producing agreement, a main problem is that climate change will affect different nations differently, with some being harmed a great deal, and others being harmed relatively little, at least over the next one hundred years. ${ }^{104}$ For example, the United States gains less from a treaty than India and African nations, for example, simply because it has far less to lose from climate change. ${ }^{105}$ If a specified level of reductions will give significant benefits to India and Pakistan, but more modest benefits to the United States and Russia, the latter nations might well be reluctant to accept that level of reductions, and might demand some kind of compensation. ${ }^{106}$

Even more troublesome, restrictions on greenhouse gas emissions will probably be most costly for high-emissions nations, including the United States. ${ }^{107}$ Indeed, the United States would have borne at least half of the total worldwide cost of the Kyoto Protocol, and perhaps significantly more than that-a point that helps explain its unwillingness to ratify the treaty. ${ }^{108}$ Large emitters, facing significant costs from emissions reductions requirements, therefore will be unlikely to join a treaty unless the treaty uses their status quo emissions as the baseline from which to determine cuts. As a practical matter, nations that are already the biggest greenhouse gas emitters will not join a treaty that requires them to reduce their emissions to the level of very poor nations; nor would they enter a treaty that requires them to pay a lot of money for permits distributed to poor nations. ${ }^{109}$

The pragmatic virtue of the status quo approach is that it takes seriously these political constraints on treaty-making. The corresponding problem with the per capita approach is that it would require smaller industrial states to buy

103. For different perspectives converging on this general conclusion, see, for example, Nordhaus, supra note 10; Nicholas Stern, The Economics of Climate Change (2007).

104. See Nordhaus \& BOYER, supra note 5, at 91.

105. Id.

106. Note in this connection that as a price for their agreement to participate in the Kyoto Protocol, Russia and Eastern Europe received emissions rights worth over \$100 billion. See Sunstein, supra note 4, at 92.

107. See Cass R. Sunstein, The Complex Climate Change Incentives of China and the United States, 55 UCLA L. REv. (forthcoming 2008).

108. See STEWART \& WiENER, supra note 1, at 49-52.

109. The qualification, of course, is that if technological innovation sharply drives down the cost of emissions reductions, large emitting nations will be more willing to accept significant restrictions. But there is no sign, at the present, of any such innovation. 
permits from larger developing states, violating International Paretianism. There is little reason that the rich states would be willing to agree to such an approach. The behavior of the United States, with respect to the Kyoto Protocol, is revealing in this regard. The United States would have had to spend over $\$ 300$ billion to comply with its obligations; ${ }^{110}$ it is no accident that no member of the United States Senate, Democratic or Republican, supported ratification. $^{111}$

To be sure, most wealthy nations send foreign aid to developing nations, so it would be a mistake to define their national interests in purely economic terms. ${ }^{112}$ We have noted that nations are capable of being altruistic. A country's national interest might be understood as some combination of altruistic and economic interests. The nature of this combination will vary with domestic political pressures. To the extent that powerful domestic constituencies want to assist those in other nations, the altruistic elements will be magnified. One might argue that, given the current level of altruism, nations would be willing to adopt the per capita approach.

The problem is that the existing level of foreign aid is probably not greatly lower than the amount that rich states are willing to pay in order to be altruistic. Such nations are unlikely to agree to massive increases in the redistribution of wealth by entering a climate treaty that requires them to bear most of the cost of greenhouse gas abatement. One risk is that if they agree to a treaty that redistributes wealth, rich states will be tempted to cut back on foreign aid, so that the redistributive effect of the treaty will be minimal or zero. Consider a few numbers in this regard. In 2006, the United States gave almost $\$ 24$ billion in foreign aid (a third of which was to Iraq). ${ }^{113}$ As noted, the politically unacceptable Kyoto Protocol would have cost the United States over $\$ 300$ billion over the indefinite future, the equivalent of perhaps tens of billions of dollars per year. ${ }^{114}$ The per capita approach, as compared to the status quo approach, would cost the United States far more than that: as much as $\$ 100$ billion per year for the indefinite future. ${ }^{115}$ There is no sign that the United States would be willing to pay that amount, well in excess of its existing foreign aid budget, as part of a climate change agreement.

In sum, the feasibility problem with the per capita approach is that it conflicts with the state system that currently organizes the world. States might well be willing to enter a climate treaty that mitigates climate change if the treaty creates restrictions that work off existing levels of greenhouse gas

110. See SunStein, supra note 4, at 95.

111. S. Res. 98, 105th Cong. (1997).

112. See Alesina \& Dollar, supra note 102.

113. See Org. for Econ. Co-Operation \& Dev. [OECD], Dev. Assistance Comm. [DAC], U.S. Aid At-a-Glance (2006), available at $\mathrm{http} / / / \mathrm{www}$.oecd.org/dataoecd/42/30/40039096.gif.

114. See NordHaus \& BOYER, supra note 5, at 166.

115. See supra note 29. 
emissions. Doing so would serve their national interests. But given the current level of altruism that appears to exist, they are highly unlikely to adopt a distributive goal like that mandated by the per capita approach. To insist on the per capita approach, then, is most likely to subvert the best chance for a climate treaty and hence to render the climate change problem intractable. ${ }^{116}$

\section{B. Defective Governance and Alternative Means to Redistribute}

As is well known in the development literature, redistributing wealth to poor nations is not easy or obvious. ${ }^{17}$ Large cash grants to governments are often siphoned off by corrupt officials. Loans are similarly abused and often not repaid. Grants and loans not lost to corruption are nonetheless often wasted because the recipient government lacks the expertise and institutional capacity to identify problems, monitor the disbursement of funds, and use them wisely. ${ }^{118}$ Donors have devised numerous means for monitoring and controlling the use of funds, but these often fail and frequently generate resentment. In some cases, donors misunderstand the needs of the recipient countries and squander funds on projects that do not help people who live there; in other cases, donors impose conditions that are politically controversial and even destabilizing. ${ }^{119}$ Donors have also tried to circumvent corrupt or inept governments by directing aid to individuals and NGOs rather than governments. But small recipients are hard to monitor and control and have limited impact, and aid programs involving multiple recipients are difficult to coordinate. ${ }^{120}$ Painful trial and error have suggested some promising approaches, which emphasize decentralization, sensitivity to context, and experimentation. ${ }^{121}$ Whatever the merits and demerits of these approaches, at least they do not repeat the errors of the past.

Now consider a climate treaty, which most likely would require the allocation of valuable permits to the governments of poor states, the same corrupt or ineffective governments that have misused foreign aid. It seems

116. For a sophisticated demonstration of this problem, see Altamirano-Cabrera \& Finus, supra note 6 (arguing that equitable schemes are more likely to be unstable than "pragmatic" schemes that take account of relative economic power).

117. For pessimistic empirical assessments of the relationship between aid and economic growth, see Simeon Djankov et al., Does Foreign Aid Help?, 26 Cato J. 1 (2006); William Easterly et al., Aid, Policies, and Growth: Comment, 94 Am. Econ. Rev. 774 (2004); Robert J. Barro \& Jong-Wha Lee, IMF Programs: Who Is Chosen and What Are the Effects? (NBER Working Paper No. 8951, 2002), available at http://papers.ssm.com/sol3/ papers.cfm?abstract_id $=313652$.

118. See, e.g., William Easterl.y, The White Man's Burden 60-112 (2006).

119. Simeon Djankov et al., The Curse of Aid (Universitat Pompeu Fabra Working Paper, 2006), available at www.cato.org/pubs/journal/cj26n1/cj26n1-1.pdf.

120. See, e.g., Arnab Acharya et al., Aid Proliferation: How Responsible Are the Donors? (IDS Working Paper No. 214, 2004), available at www.ids.ac.uk/ids/bookshop/wp/wp214.pdf (pointing out the costs to donee countries of dealing with multiple donors).

121. See Easterly, supra note 117. 
highly likely that some of these governments would misuse these permits as well, for example, by transferring them to cronies. ${ }^{122}$

Even if the governments of developing countries are not corrupt, they will still not necessarily use revenues from permits in the way that donor countries, motivated by altruism, would approve. Recall that the per capita approach was justified by redistributive concerns: all else being equal, a climate pact that favored developing nations would be desirable. If large countries tend to be poor, then the per capita approach has attractive redistributive features. The redistributive approach is even better than the per capita approach, on this view. But if the redistributive approach is not practicable, the per capita approach might be second best.

Any realistic climate treaty will do no more than allocate permits to the governments of developing nations. After these nations sell the permits, they will be free to use the revenue however they wish. But the governments of developing nations are not particularly generous to their poor. In a state like Guatemala, for example, taxes are low, apparently because wealthy people disproportionately influence the political process. ${ }^{123}$ It seems unlikely that the Guatemalan government, having received a windfall of permits, would redistribute the revenues to the poor. More likely, the government would simply lower taxes on the wealthy even more. The per capita approach or redistributive approach, therefore, would not end up helping the very poor; these approaches would end up helping wealthy people who live in poor countries.

Even worse, the development literature has identified the "resource curse," the idea that poor states that enjoy rich natural resources do worse, politically or economically, than poor states that do not. ${ }^{124}$ Theories abound for this phenomenon; one such theory is that a large pool of resources in a state with poor institutions encourages insurgencies, since the insurgents can finance the conflict by seizing control over the resources. The resource curse also has been cited as a possible explanation for the ineffectiveness of foreign aid: a windfall of foreign aid is like the discovery of oil, and may be similarly destabilizing. ${ }^{125}$ If this theory is right, distributing valuable permits to poor countries may cause civil war rather than prosperity.

Whether these theories are sound or not, the point for present purposes is that repeating the errors of development policy by using a climate treaty as an opportunity to engage in foreign aid would be hazardous. The distribution of

122. See Posner \& Sunstein, supra note 41.

123. See, e.g., U.N. Hum. Rts. Council [UNHRC], Report of the Special Rapporteur on Extrajudicial, Summary or Arbitrary Executions, Civil and Political Rights, Including the Questions of Disappearances and Summary Executions, Addendum, Mission to Guatemala (21-25 August 2006), fi 58-61, U.N. Doc. A/HRC/4/20/Add.2 (Feb. 19, 2007) (prepared by Philip Alston).

124. See AuTY, supra note 58.

125. See Djankov, supra note 119. 
permits on a per capita basis, in order to favor poor states, would be just such an effort. If giving piles of cash to poor states has failed to help them, then giving them piles of permits will also fail to help them. To the extent that this is so, they should receive no more permits than are necessary to induce them to internalize the external climate effects of polluting activity.

\section{CONCLUSION}

From the standpoint of both welfare and fairness, there are strong arguments for large amounts of international redistribution. If resources from wealthy people in wealthy nations could be transferred to poor people in poor nations, global welfare would be significantly increased. At the same time, arguments from fairness suggest that people should not have far worse prospects in life simply because of the nation in which they are born. These arguments have led many analysts to suggest that the per capita approach is the best way to allocate greenhouse gas emission rights. In the developing world, that approach has widespread support, ${ }^{126}$ and there is no question that it will be pressed aggressively in international negotiations.

We have urged that claims from both welfare and fairness fail to provide strong justifications for the per capita approach. A central problem is that some wealthy nations have large populations and some poor nations have small populations. Per capita allocations of emissions rights would result in substantial benefits for China and India, both of which are poor. But many nations are significantly poorer than those nations, and a directly redistributive approach would be a far more effective way of assisting those who need help. Moreover, any international agreement will benefit some nations more than others and cost some nations more than others. In these circumstances, the per capita approach gives the appearance, not the reality, of fairness.

It remains true that from the standpoint of welfare and fairness, per capita allocations would be far better than the status quo approach. But here, as elsewhere, the best is the enemy of the good. A climate treaty that included the optimal level of emissions would be good. A climate treaty that included the optimal level of emissions reductions and the optimal level of redistribution would be better still. But such a treaty is much less likely to be possible. On welfarist grounds, and putting incentive effects to one side, the redistributive approach is superior to the per capita approach, which is in turn superior to the status quo approach. Unfortunately, the best approaches in principle are also least likely to be feasible in practice.

We have not attempted here to say exactly how emissions rights should be allocated; our modest goal has been to challenge the widely held view that per capita allocations should be the foundation for an international agreement. But a more general point does emerge, and it is ironic and potentially even tragic.

126. See VANDERHEIDEN, supra note 6, at 66-69. 
Because of the constraints of feasibility, the insistence by poor nations on the best approaches in principle would likely undermine current efforts to convince the world to take significant steps to reduce greenhouse gas emissions-and as a result would most harm those very nations that are especially vulnerable to the effects of climate change. ${ }^{127}$

127. For a clear demonstration of their greater vulnerability, see Climate Change Risk REPORT, supra note 40. 
